\title{
Sex differences and considerations for female specific nutritional strategies: a narrative review
}

\author{
Kealey J. Wohlgemuth', Luke R. Arieta', Gabrielle J. Brewer', Andrew L. Hoselton', Lacey M. Gould ${ }^{1}$ and \\ Abbie E. Smith-Ryan ${ }^{1,2^{*}}$ (D)
}

\begin{abstract}
Although there is a plethora of information available regarding the impact of nutrition on exercise performance, many recommendations are based on male needs due to the dominance of male participation in the nutrition and exercise science literature. Female participation in sport and exercise is prevalent, making it vital for guidelines to address the sex-specific nutritional needs. Female hormonal levels, such as estrogen and progesterone, fluctuate throughout the mensural cycle and lifecycle requiring more attention for effective nutritional considerations. Sexspecific nutritional recommendations and guidelines for the active female and female athlete have been lacking to date and warrant further consideration. This review provides a practical overview of key physiological and nutritional considerations for the active female. Available literature regarding sex-specific nutrition and dietary supplement guidelines for women has been synthesized, offering evidenced-based practical information that can be incorporated into the daily lives of women to improve performance, body composition, and overall health.
\end{abstract}

Keywords: Women's health, Human performance, Menstrual cycle, Dietary supplement, Female, Macronutrients

\section{Introduction}

Now, more than ever, there is a high prevalence of female participation in physical activity and sport $[1,2]$. There is also a growing awareness of the potential impact of cyclical menstrual hormones (i.e. estrogen and progesterone) on exercise performance [3] and metabolic demand [4], making it important to understand physiological differences and address female specific nutritional needs [5]. Over the course of the menstrual cycle, it is important to note that women may have different caloric and macronutrient needs due to fluctuations in sex hormones, substrate reliance, and increased energy demand during exercise [6, 7]. Macronutrient

\footnotetext{
* Correspondence: abbsmith@email.unc.edu

'Department of Exercise and Sport Science, University of North Carolina at Chapel Hill, Chapel Hill, NC 27599, USA

${ }^{2}$ Department of Nutrition, Gillings School of Public Health, University of North Carolina, Chapel Hill, NC 27599, USA
}

ranges vary per individual depending on menstrual cycle, energy demands, and/or body composition goals [8-10]. These ranges should be primarily met with whole foods; however, key dietary supplements may be beneficial to females to support improvements in performance, recovery, and overall health [11]. In addition to physiological sex differences, there are notable reported behavioral differences between males and females, such as males wanting to be larger with more muscle mass, while females tend to want to be leaner and have reported more attempts to lose weight $[12,13]$. It is also known that most female athletes under consume calories [14, 15]; however, it is vital for overall health and performance that women meet their caloric needs to maintain energy availability and regular menstruation [16, 17]. To date, there are few resources that provide a physiological rationale for sex-specific nutritional needs and dietary guidelines for women, particularly in a single resource.

C C The Author(s). 2021 Open Access This article is licensed under a Creative Commons Attribution 4.0 International License, which permits use, sharing, adaptation, distribution and reproduction in any medium or format, as long as you give appropriate credit to the original author(s) and the source, provide a link to the Creative Commons licence, and indicate if changes were made. The images or other third party material in this article are included in the article's Creative Commons licence, unless indicated otherwise in a credit line to the material. If material is not included in the article's Creative Commons licence and your intended use is not permitted by statutory regulation or exceeds the permitted use, you will need to obtain permission directly from the copyright holder. To view a copy of this licence, visit http://creativecommons.org/licenses/by/4.0/ The Creative Commons Public Domain Dedication waiver (http://creativecommons.org/publicdomain/zero/1.0/) applies to the data made available in this article, unless otherwise stated in a credit line to the data. 
This review aims to provide an evidence-based, but practical overview, for nutrition and dietary supplements in healthy eumenorrheic women.

\section{Physiological sex differences}

Understanding physiological sex-based differences between men and women may help optimize nutritional strategies chosen to support certain goals ranging from maximizing exercise performance to gaining lean mass or losing weight. Important sex-differences exist in substrate utilization [18], thermoregulation [19], fatigability [20], soreness and recovery [21], and body composition [22]. Prior to puberty, males and females demonstrate similar substrate metabolism [23]; in adulthood estrogen has a large regulatory role in fat metabolism [24]. Once completing the transition through puberty, if caloric intake is adequate, women typically experience regular menstrual cycles, predictable fluctuations of ovarian hormones, and are considered eumenorrheic until they begin the menopause transition (average age of onset is 51 years). A regular menstrual cycle lasts an average of 28 days (ranging from 21 to 45 days) and consists of two main phases: the follicular phase and the luteal phase (Fig. 1) [25]. At the beginning of the follicular phase (
14 days), menstruation occurs and hormones, including estrogen, specifically $17 \beta$-oestradiol (estradiol), progesterone, follicle stimulating hormone (FSH), and luteinizing hormone (LH) are at their lowest baseline levels [25, 26]. Around day 4-5 of menstruation, the mid-follicular phase begins, and estrogen and FSH levels rise to prepare the body for ovulation. At the end of the follicular phase (day 11-13), LH spikes and induces ovulation, while estrogen rises and then falls following ovulation. The luteal phase (14 days) begins after ovulation occurs; LH and FSH decline and return to baseline levels while progesterone and estrogen levels peak around day 20-24 (mid-luteal phase) to prepare the body for pregnancy. If pregnancy does not occur, hormone levels return to baseline and induce menstruation, signaling the beginning of a new menstrual cycle [27].

It is important to consider the effects of the menstrual cycle on metabolism and performance as women exercise and compete in every phase of their cycle, and may be able to optimize nutritional strategies based on these influences. Substantial evidence suggests that estrogen is a master regulator of both body composition and bioenergetics, so the fluctuation of estradiol throughout the menstrual cycle may have important implications for

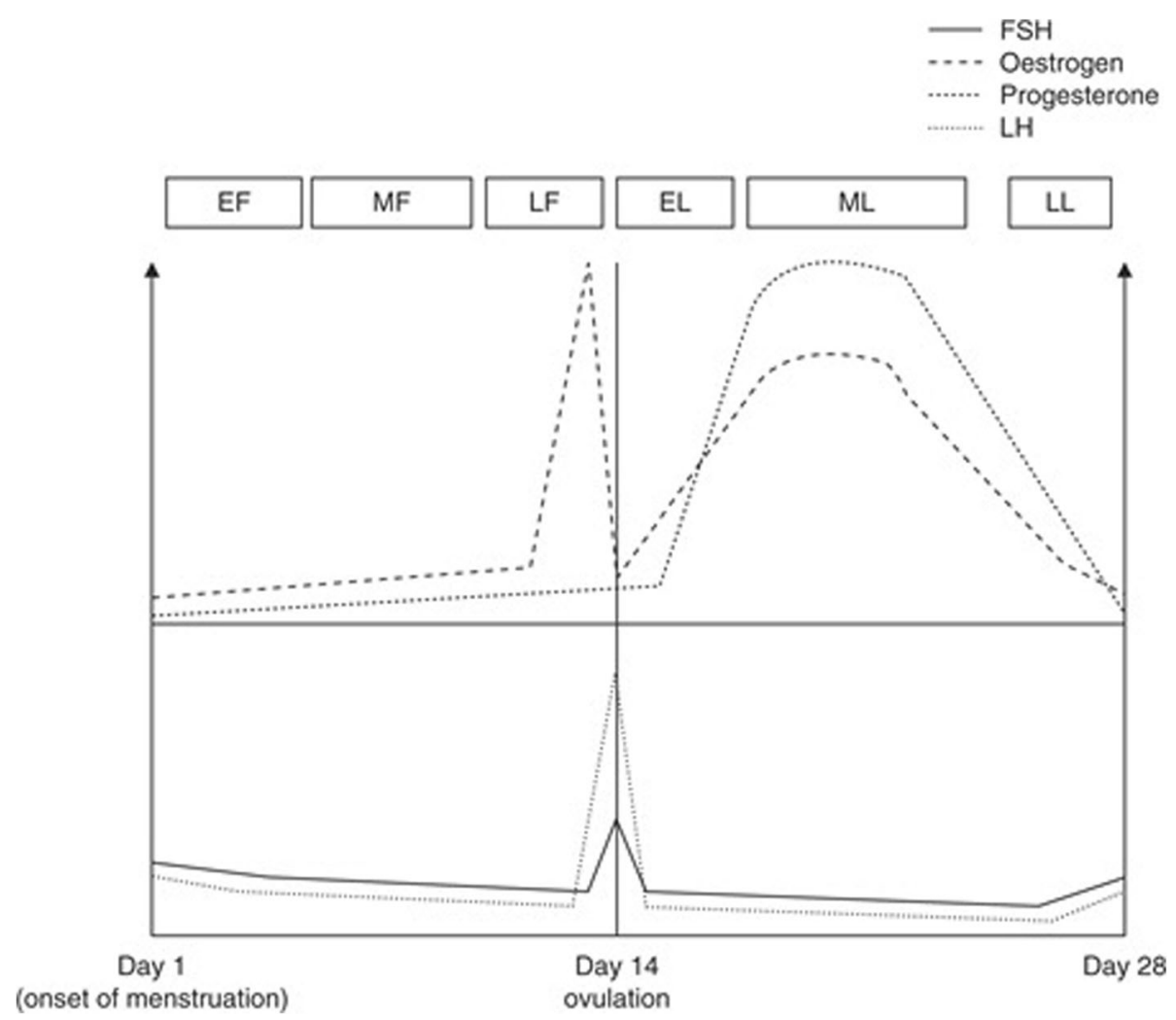

Fig. 1 Female sex hormones fluctuate cyclically and predictably throughout the menstrual cycle. Estradiol is the primary estrogen secreted, and it is depicted as estrogen in this figure. The phases are defined as follows: $\mathrm{EF}=$ early follicular; $\mathrm{EL}=$ early luteal; FSH = follicle stimulating hormone; $\mathrm{LF}=$ late follicular; $\mathrm{LL}=$ late luteal; $\mathrm{MF}=$ mid follicular; $\mathrm{ML}=$ mid luteal. This diagram was adapted from Oosthuyse \& Bosch (2010) [25] 
exercise capacity and nutrition [28]. At rest, women exhibit heightened fat oxidation, as indicated by decreased respiratory exchange ratio (RER), and $2.5-11.5 \%$ higher resting energy expenditure (REE) during the luteal phase of the menstrual cycle when ovarian hormones peak [24, 29, 30]. However, consistent exercise training may also dictate substrate utilization and improve fat oxidation efficiency in men, which is supported by insignificant differences in RER between endurance-trained males and females [6]. While studies that utilize indirect calorimetry have provided substantial evidence for increased fat oxidation at rest in women, this methodology is unable to quantify protein catabolism. Through measuring circulating amino acids in the bloodstream and urine, studies have found that protein oxidation is also greater at rest in women during the luteal phase [31, 32]. Taken together, these findings indicate that increased metabolism of fat and protein occurs during the luteal phase, which is accompanied by greater caloric expenditure, and possibly appetite. Figure 2 depicts the impact of menstrual cycle phase on metabolism and performance [25].

\section{Aerobic exercise}

Because sex hormones like estradiol may influence metabolism and other aspects of physiology at rest and during exercise, it is important to consider how sex hormones affect exercise performance. Understanding when performance may be naturally augmented or impeded by the menstrual cycle may allow women to optimize their nutrition. Evidence suggests that increased estradiol in the luteal phase spares muscle glycogen by promoting oxidation of free fatty acids (FFA), which would have implications for improved endurance performance [25]. During submaximal exercise of the same intensity, adult women generally metabolize more fat compared to men, which is indicated by a lower RER [33, 34]. A more recent review details that women may confer an advantage in ultra-endurance competition [35]. Although research assessing prolonged-duration exercise in women is scarce, it is hypothesized that ultra-distance $(>2 \mathrm{~h})$ performance may be impaired due to the suppression of gluconeogenic output when estrogen and progesterone are at high levels (i.e. luteal phase) [36]. One study assessed time to exhaustion (TTE), a proxy for endurance performance, following glycogen depletion exercise during their follicular and luteal phases, and found that exercise in the luteal phase produced a 10\% longer TTE and was associated with greater glycogen repletion [37]. A different study found that time trial performance was $13 \%$ better in the follicular phase following $120 \mathrm{~min}$ of cycling at $70 \%$ maximal oxygen consumption $\left(\mathrm{VO}_{2} \mathrm{max}\right)$,

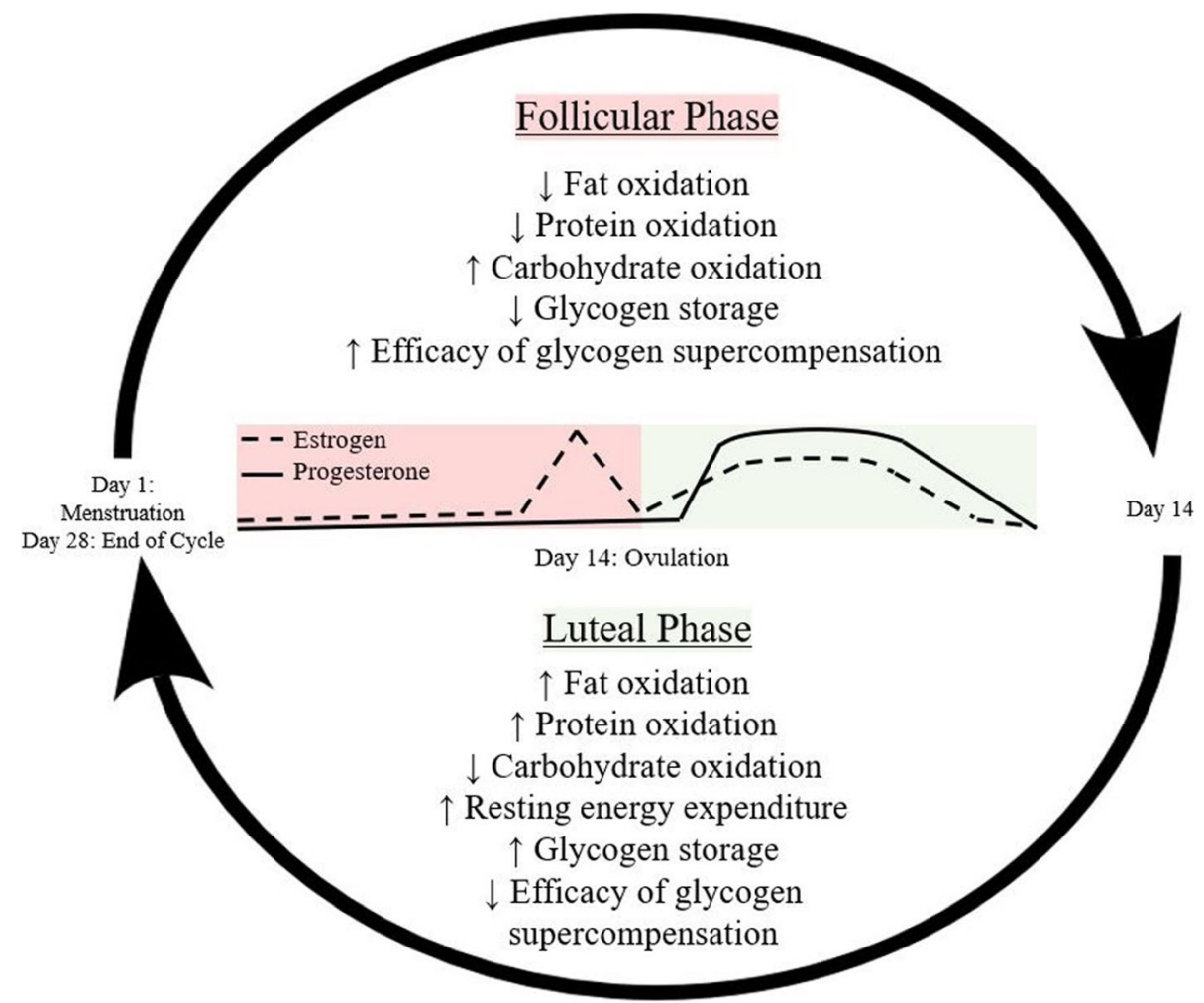

Fig. 2 Nutritional needs throughout the menstrual cycle may change based on physiological implications from estrogen and progesterone. Key metabolic adaptations are described for the follicular and luteal phases 
indicating that intense exercise may be supported better by increased glucose kinetics in the follicular phase [7]. While it is not feasible to modify competition dates around the menstrual cycle, based on this data, it may be beneficial to increase carbohydrate consumption to support higher glycogen levels, during the luteal phase. Ovarian hormones have generally been found ineffective in altering short-duration or maximal effort exercise, however, one study found that $\mathrm{VO}_{2}$ max was $2 \%$ lower in the mid-luteal phase [38-40]. The effects of oral contraceptives on performance is unclear; however one study demonstrated that $\mathrm{VO}_{2} \max$ was reduced by $11 \%$ in women who consumed oral contraceptives for 4 months [41]; these effects are likely related to the type of contraception.

\section{Strength \& Power}

To date, most literature suggests that the menstrual cycle does not directly influence strength or power exercise performance. One study tested half-squat 1 repetition maximum (1RM) in resistance-trained women during their early follicular, late follicular, and mid-luteal phases; this group measured force production, velocity, and power at loads equivalent to $20,40,60$, and $80 \%$ of their $1 \mathrm{RM}$ and found similar results across all three menstrual phases [42]. Taken together, the menstrual cycle likely impacts endurance performance, but not resistance performance, by altering substrate utilization, which may be further impacted by the ratio of the magnitude of increase in estrogen and progesterone in the luteal phase [25]. Indirectly, other aspects of the menstrual cycle may influence both endurance and strength/ power activities. Specifically, sex differences in fatiguability, thermoregulation, and body composition should be considered.

\section{Fatiguability}

A recent review reports that fatigability differs between men and women, with women being less fatigable during single-limb isometric contractions [20]. Women proportionally have greater area of type I muscle fibers in numerous muscle groups, which is a proposed mechanism to support reduced fatigability in women during isometric contractions [43]. Another study found similar results regarding dynamic contractions, when the load was low and contractions were slow-velocity, women were less susceptible to fatigue [44]. Collectively, available data suggest that men and women may respond differently to training that involves fatiguing contractions and may require altered recovery and nutritional support. While women appear to be less fatigable during exercise, it is also important to consider sex-differences in the recovery period following exercise. Hormonal fluctuations from the menstrual cycle have been shown to alter recovery rates in women. A recent study in 8 trained, eumenorrheic females reported that markers of muscle damage (creatine kinase) and inflammation (interleukin6) following $90 \mathrm{~min}$ of running at $70 \% \mathrm{VO}_{2} \max$ were substantially greater during the follicular phase compared to the mid-luteal phase [21]. Thus, nutrition and exercise recommendations should consider phase of the menstrual cycle to maximize performance and recovery. Specifically, recovery rates may be impeded in the follicular phase. Additionally, females report greater blood flow and lower metabolic acidosis, particularly during intermittent exercise [45]; consequently, higher intensities and shorter rest periods, as well as variation in dietary supplements that delay fatigue, may need a sexspecific lens.

\section{Thermoregulation}

Thermoregulation may vary between sexes; during heat exposure, the onset of sweating was delayed and resulted in lower volume in women compared to men [46, 47]. Interestingly, when men and women are matched for age, acclimatization, body size, and fitness level, differences in thermoregulation no longer persist, however, many studies fail to control for the menstrual cycle in females [48]. Issues related to thermoregulation likely impact women to a greater extent than men because the luteal phase of the menstrual cycle is associated with higher core body temperature, greater cardiovascular strain during submaximal steady-state exercise, and a heightened threshold for the onset of sweating [19, 49, 50]. It may be important to increase fluid intake during the luteal phase, as well as evaluate sweat rates during the various phases of the cycle to identify a woman's fluid requirements and alterations.

\section{Body composition}

In regard to body composition, it is important to remember that there are innate sex differences. Men generally have more lean mass (LM), while women have more fat mass (FM) and higher body fat percentage (\%fat); men are more susceptible to gaining abdominal fat (android), whereas women usually carry more fat in the hip (gynoid) region [22]. Men and women may also respond differently to training and diet interventions, in regard to body mass and composition. A 24-week diet or diet plus exercise intervention was shown to significantly decrease body mass at three months $(-7.4 \pm 0.5 \%$ for diet and $-5.8 \pm 0.3 \%$ for diet plus exercise) and at six months $(-10.4 \pm 0.9 \%$ for diet and $-10.1 \pm 0.9 \%$ for diet plus exercise) compared to consuming a weight maintenance diet, but there was no effect for sex [51]. Similarly, there was no effect for sex on FM deduction; however, men lost a significantly greater amount of visceral adipose tissue in both intervention groups 
compared to women. No sex differences were seen in subcutaneous adipose tissue. Fat free mass (FFM) was reduced from baseline in all three groups at both three and six months for women, while men in the diet plus exercise had no significant reduction in FFM from baseline at three months and no reduction at three or six months for those consuming maintenance calories. A study assessing a three-week training and diet intervention on age and BMI matched obese males and females found that body mass was significantly reduced in both groups, but that men lost a greater percentage of their initial body mass [52]. Perhaps more importantly, men lost both FM and LM in similar amounts whereas women lost mostly FM. More recent data has suggested women are more resilient in maintaining LM under caloric restriction [53]. These distinct differences may be especially important with advancing age due to their influence on functional performance. Leg lean mass was shown to be associated with balance in older women in addition to a greater weight to leg lean mass ratio being predictive of performance during gait tasks, but neither relationship exists in older men [54]. Lastly, bone mineral density (BMD) can be evaluated to measure risk or current levels of osteoporosis or osteopenia by assessing bone mass [55]. Previous literature has reported that BMD decreases in both sexes with age; however, in adult to elderly women BMD is significantly lower than men, which may lead to increased osteoporotic fractures, so training and nutrition in women should be optimized to prevent loss of BMD [55].

\section{Overview of types of birth control on hormones}

There are numerous contraception options available that can alter hormone fluctuations, including both hormonal and non-hormonal options. At the minimum, it would be important to identify what type of contraception a female is using, in order to better understand the potential implications, it may have on hormonal fluctuations, if any, and thus help guide nutritional recommendations. Only hormonal contraceptives will be discussed here, and in particular their influence on exercise rather than discussing their efficacy in regard to preventing pregnancy or their potential non-contraceptive benefits, such as decreasing ovarian cancer risk [56]. Hormonal contraceptives are available to be taken orally (a pill), as a patch for transdermal administration, as a vaginal ring, along with implants (e.g. in the upper arm) and intramuscular injections [57]. A data brief from the National Center for Health Statistics [58] estimated that $64.9 \%$ of all women aged 15-49 years in the United States are using some form of contraception with the oral contraceptive pill (OC) reported as the most common form of exogenous hormonal contraceptive. In general, OC consists of an estrogen (e.g. ethinyl estradiol or mestranol) and a progestin (e.g. norethindrone, norethindrone acetate, ethynodiol diacetate, norgestrel, or norethynodrel) [59]. To imitate the rising and falling of hormones over the course of the menstrual cycle, OC have phases [60]. Monophasic OC consist of the same estrogen and progestin levels throughout the cycle, while biphasic OC will maintain the same hormone levels for the first half of the cycle; however, progestin levels will increase halfway through the cycle, and triphasic pills have variations in hormones every 7 days [60,61]. Different doses and types of progestin taken have been shown to have negative effects on plasma glucose, insulin, and C-peptide response to a glucose tolerance test [62]. Although, low doses of seven different types or concentrations of progestogen resulted in no change in glucose metabolism over six months [63]. During exercise, triphasic OC have been shown to decrease glucose flux and may reduce insulin action [64]. Lipid profiles may also be altered in women taking $\mathrm{OC}$ as a recent meta-analysis concluded that most progestins increase the concentrations of both triglycerides and high-density lipoprotein cholesterol, but effects on low-density lipoprotein cholesterol varied [65]. However, some have shown no difference in substrate utilization or hormonal response to 45-min of exercise at $65 \% \quad \mathrm{VO}_{2} \mathrm{max}$ in eumenorrheic women compared to women taking low-dose oral contraceptives [24], while others have shown increased glycerol appearance, indicative of triglyceride mobilization, and increased cortisol during exercise in women taking OC [66]. It should be noted that the use of a monophasic and triphasic $\mathrm{OC}$, respectively, could potentially explain the differences seen. Oral contraceptive pills may have a negative influence on inflammatory markers as evidenced in elite Olympic level female athletes who were using oral contraceptives as they displayed higher levels of C-reactive protein, a marker of inflammation, than eumenorrheic peers, potentially suggesting increased muscle damage or inadequate recovery [67]. A study assessing less elite but still highly active females found similar results as those taking $\mathrm{OC}$ had higher levels of high-sensitivity $\mathrm{C}$-reactive protein than non-OC users [68]. Further, there was no difference in cycling endurance performance [69] or swimming performance [70] in trained females taking a monophasic OC throughout a single OC cycle. However, triphasic OC have been shown to result in decreased aerobic capacity compared to no OC use $[41,71]$. There was no difference in leg extensor isometric maximal muscular strength or 1repetition maximum between $\mathrm{OC}$ users and non-users following 10-weeks of progressive lower body resistance training [72]. Interestingly, there was a trend $(P=0.06)$ towards a greater increase in muscle cross-sectional area in those taking $\mathrm{OC}$, and this trend was driven by a greater increase in CSA from those taking OC with 
$30 \mu \mathrm{g}$ compared to $20 \mu \mathrm{g}$ ethinyl estradiol. Due to the plethora of females who use contraceptives, it is important to understand the different types available and the influence they may have on the body, specifically, on metabolism and performance. While some physiological variables may be altered during exercise with hormonal contraceptive use, careful attention should be paid to the type of and concentration of the exogenous hormones as these may elicit distinct responses.

\section{Caloric intake considerations}

A primary nutrition consideration for women should be achieving adequate caloric intake, particularly with increased levels of physical activity, in order to support cellular function and performance demands. Previous data evaluating dietary intake and eating habits of female athletes reported that the majority of athletes under consumed calories, in particular carbohydrates [14]. Failure to reach sufficient metabolic and caloric demands may elicit disruptions to menstruation, performance, and bone mass, potentially increasing the risk for injury and osteoporosis [17, 73].

Energy availability (EA) is the remaining dietary energy in the body after the energy expenditure from physical activity has been considered [74]; this remaining dietary energy is available to be utilized in the body's metabolic processes [75]. Failure to habitually maintain adequate caloric intake necessary for metabolism may result in health consequences and performance determinants, which is particularly prevalent among women [14]. These consequences may be further exacerbated with the addition of physical activity, particularly with increased intensity and duration of exercise. Previous data reported that 5 consecutive days of low EA $(<30 \mathrm{kcal} / \mathrm{kg}$ fat-free mass/day) in women resulted in a reduction of carbohydrate availability [74], which would have direct implications on exercise performance.

Obtaining optimal EA (40-45 kcal/kg FFM/day), eumenorrhea, and bone health are essential to sustaining metabolism and maximizing performance in women [76]. Lack of proper nutrition may lead to Relative Energy Deficiency in Sport (RED-S)/Female Athlete Triad (Triad) [77]. RED-S and the Triad both refer to disordered eating, or under consumption, and osteoporosis; the Triad includes amenorrhea as an additional consideration for women. In the absence of a menstrual cycle, Disordered eating often leads to energy imbalances and deficits which can result in amenorrhea, decreased performance, and in severe cases death. Amenorrhea, or the absence of a menstrual cycle, would result in different nutritional recommendations as discussed here due to the lack of cyclical hormone variation. Specifically, amenorrhea is characterized by a lack of ovulation as a result of insufficient luteinizing hormone and follicular stimulating hormone; both of which would impact estrogen and progesterone concentrations. For specific nutritional recommendations for amenorrhoeic athletes see Benson et al. [78]. Osteoporosis is defined as a bone mineral density (BMD) below 2.5 standard deviations of a young healthy adult and leads to porosity of the bones increasing the chances of fracture [79]. While these conditions can occur independently, low BMD is often an indicator of menstrual disturbances in younger women [79]. Combined, the effects of RED-S or the Triad behaviors influence metabolic function, muscle protein synthesis, bone health, immunity, and cardiovascular health; all of which may alter daily living and both shortand long-term performance [80]. Best practices to avoid RED-S or the Triad include adequate caloric intake to meet energy, metabolic, and activity demands and sufficient intake of proper macronutrients. In addition to achieving optimal EA, it may be advantageous to increase caloric intake and certain macronutrients throughout certain phases of the menstrual cycle. Previous data regarding REE through the cycle suggests dayto-day variability, with some women experiencing an increase up to $2.5-11.5 \%$ during the luteal phase $[29,81]$. Once the caloric needs have been met, addressing nutrient timing of carbohydrates, fats, and protein may be advantageous to further optimize performance and recovery.

\section{Carbohydrates}

Carbohydrates serve as a vital fuel source during moderate to high intensity exercise [82]. Currently, the acceptable macronutrient distribution range (AMDR) for carbohydrates is $45-65 \%$ of total calories [82], with additional recommendations of $6-10 \mathrm{~g} / \mathrm{kg} /$ day in active populations looking to maximize performance [83]. Ultimately, carbohydrate needs are largely dependent upon the length and intensity of training or competition, with longer more intense activities exacerbating the demand [84]. Strategic implementation of carbohydrates around an exercise bout is essential to ensuring carbohydrate availability [85]. Sex differences and the variations in sex hormones over the menstrual cycle also influence the utilization and storage of carbohydrates [86] and must be considered.

The correlation between endurance exercise performance and pre-exercise muscle glycogen content [87] suggests that carbohydrate loading programs can increase performance [86]. With most of the carbohydrate loading studies involving men, it was assumed that that similar guidelines would be applicable to females [88]. However, previous research shows that men and women differ in the ability to carbohydrate load following the same protocol. Tarnopolsky et al. [89] implemented a feeding protocol that increased daily carbohydrate intake 
from 55 to 60 to $70 \%$ energy intake in trained male and female cyclists over a 4-day tapering period. The females, who were in the follicular phase of the menstrual cycle exhibited no significant changes in muscle glycogen content or performance on a submaximal endurance test, while males improved on both parameters (41 and $45 \%$, respectively). Although the relative carbohydrate intake was equal among the sexes, the elevated overall energy intake in males resulted in greater absolute carbohydrate intake. Thus, for females, emphasis must be placed on adhering to $\mathrm{g} / \mathrm{kg}$ recommendations. Walker and colleagues [9], further investigated the effects of carbohydrate loading programs in trained women during the luteal phase of the menstrual cycle. A high carbohydrate diet $(8.2 \mathrm{~g} \mathrm{CHO} / \mathrm{kg} \mathrm{BM} /$ day $)$ resulted in significantly higher muscle glycogen content (13\%) and improved performance on a submaximal endurance test compared to moderate carbohydrate diet $(4.7 \mathrm{~g} / \mathrm{kg} \mathrm{BM} /$ day). Furthermore, James et al. [90] examined the effects of a 3-day high carbohydrate diet ( $12 \mathrm{~g} \mathrm{CHO} / \mathrm{kg} \mathrm{LBM})$ on muscle glycogen content in endurance trained males and females. Muscle glycogen content significantly increased in response to the high carbohydrate diet in both sexes and during both menstrual cycle phases. Practically, females can carbohydrate load in either phase of the menstrual cycle by adhering to the recommendation of $8-10 \mathrm{~g} \mathrm{CHO} / \mathrm{kg} \mathrm{BW}$ in the 3 days leading up to an event. With lower chronic $\mathrm{CHO}$ intakes, glycogen storage appears to be more effective with the short term increase in $\mathrm{CHO}$ in the luteal phase [25].

Current recommendations call for a carbohydrate intake of $1-4 \mathrm{~g} / \mathrm{kg} \mathrm{BW}$ in the $1-4 \mathrm{~h}$ prior to competition or training [84]. Consumption in this timeframe has been shown to increase muscle and liver glycogen and maintain blood glucose, potentially leading to improved performance in the upcoming task [85]. Albeit in trained male cyclists, Coyle et al. [91], determined that a high carbohydrate meal $(2 \mathrm{~g} / \mathrm{kg} \mathrm{BW}) 4 \mathrm{~h}$ prior to an exercise bout resulted in a $42 \%$ increase in muscle glycogen content within the vastus lateralis. In several other studies, consumption of a liquid carbohydrate supplement $(>4.5$ $\mathrm{g} / \mathrm{kg} \mathrm{BW}$ ) at least $3 \mathrm{~h}$ before a performance test led to performance improvements in recreational cyclists [92, 93]. While carbohydrate consumption in the hours leading up to an exercise bout has shown beneficial effects in men, data is women is less clear. Pre-exercise carbohydrate feeding is likely to be more important during the follicular phase, when carbohydrate oxidation rates are elevated [25]. Operationally, women participating in aerobic exercise should consume at least $1 \mathrm{~g} / \mathrm{kg}$ of carbohydrates in the hours leading up to an exercise bout to maximize carbohydrate availability.

The window for carbohydrate consumption does not close at the onset of exercise. Several studies have investigated the effects of carbohydrate supplementation during prolonged endurance exercise specifically over the course of the menstrual cycle. Bailey et al. [94], investigated the ergogenic effects of a $6 \%$ carbohydrate solution during a prolonged cycling bout at $70 \% \mathrm{VO}_{2} \max$ during both phases of the menstrual cycle. There was a significant increase in TTE in both phases of the menstrual cycle with a dose of $5 \mathrm{ml} / \mathrm{kg}$ of the $6 \%$ carbohydrate solution versus the placebo. A similar study assessed blood glucose during $120 \mathrm{~min}$ of cycling at $70 \%$ $\mathrm{VO}_{2}$ max followed by a time trial, with and without a carbohydrate supplement [7]. During the follicular and luteal phases, supplementing with a $6 \%$ carbohydrate solution every $15 \mathrm{~min}$ improved performance and significantly minimized differences in blood glucose concentration between menstrual cycle phases [7]. Regardless of menstrual cycle phase, administration of a $6 \%$ carbohydrate solution has been shown to improve performance during prolonged endurance exercise. Moreover, consuming 500-1000 mL of the 6\% carbohydrate solution falls well within the common guidelines for endurance athletes of 30-60 g/hr. [95].

Following a prolonged endurance exercise bout, replenishing muscle glycogen stores is a top priority [96]. In females, the capacity to restore muscle glycogen stores fluctuates over the course of the menstrual cycle with the highest capacity occurring in the follicular phase [37]. Tarnopolosky et al. [97], investigated the effects of a carbohydrate supplement on muscle glycogen resynthesis following a prolonged bout of submaximal exercise in endurance athletes. All female participants were tested in the follicular phase of the menstrual cycle. Administration of the carbohydrate supplement $(0.75 \mathrm{~g} /$ $\mathrm{kg}$ ) immediately following the exercise bout resulted in significantly greater muscle glycogen synthesis compared to the placebo, with no significant sex differences. In addition to satisfying the critical amount of carbohydrates, refueling strategies should also look to minimize the amount of time between the end of exercise and the consumption of carbohydrates. Although performed in males, Ivy [98], determined that delaying carbohydrates in the immediate post-exercise period $(2 \mathrm{~h})$ resulted in reduced glycogen storage rates. Therefore, in an ideal situation, females should focus on rapid consumption of at least $0.75 \mathrm{~g} / \mathrm{kg}$ of carbohydrate following prolonged exercise in order to restore spent muscle glycogen.

While daily carbohydrate needs are determined by length and intensity of activity, practical recommendations about carbohydrate consumption exist for the different time frames surrounding an exercise bout. In preparation for prolonged endurance exercise $(>90 \mathrm{~min})$, females might consider carbohydrate loading by consuming $8-10 \mathrm{~g} \mathrm{CHO} / \mathrm{kg} \mathrm{BW}$ in the 3 days leading up to an event, particularly if the event should occur in the 
follicular phase. In the hours before, $1 \mathrm{~g} \mathrm{CHO} / \mathrm{kg} \mathrm{BW}$ should be prioritized to ensure carbohydrate availability throughout the activity. During prolonged endurance exercise, females should consume $500-1000 \mathrm{~mL}$ of $6 \%$ carbohydrate solution per hour to experience ergogenic effects. Following exercise, females should rapidly consume at least $0.75 \mathrm{~g} / \mathrm{kg}$ of carbohydrate to begin the process of replenishing muscle glycogen stores. Of course, these recommendations should be considered along with total daily carbohydrate needs. An example for how caloric intake and macronutrients for a female athlete (soccer player) are described in Fig. 3.

\section{Fats}

Fats are essential for maintaining sex hormone concentrations and absorbing fat-soluble vitamins [16]. In females specifically, adequate fat intake may help to sustain normal menstrual cycles [99]. The current acceptable macronutrient distribution range (AMDR) for dietary fat is $20-35 \%$ of total calories [82]. In populations seeking a reduction in body fat, recommendations range from $0.5-1 \mathrm{~g} / \mathrm{kg} /$ day [100]. Additional guidelines are in place for females regarding omega- 6 (linoleic acid) and omega-3 ( $\alpha$-linoleic acid) fatty acids, calling for $12 \mathrm{~g}$ and $1.1 \mathrm{~g}$ per day, respectively [82], a 5-10:1 ratio of omega-6 to omega-3 [101]. Ultimately, females should aim to obtain at least $15 \%$ of total calories from unprocessed fat sources like lean meats, nuts, seeds, eggs, and avocados [99].

The variations in female sex hormones during the follicular and luteal phases of the menstrual cycle influence fat metabolism [102]. Elevated estrogen levels during the luteal phase promote lipolysis through increased sensitivity to lipoprotein lipase and increased human growth hormone [103]. During the follicular phase, estrogen levels are lower, resulting in a reduced reliance on fat as an energy substrate [102]. These phenomena persist during submaximal exercise (35-60\%) as Hackney et al. [104] demonstrated greater reliance on fat oxidation in the luteal phase versus the follicular phase. Thus, adequate dietary fat intake, particularly during the luteal phase, is essential to account for upregulated fat metabolism.

Previous research has shown that females exhibit lower RER than males during submaximal endurance exercise; therefore, suggesting that females rely more on fat oxidation than males $[89,105,106]$. There also appears to be sex differences in the source of lipids used during submaximal endurance exercise; females used significantly more myocellular triacylglycerol than males during a 90-min bout of cycling at 58\% $\mathrm{VO}_{2} \max$ [6]. Consuming a high fat diet (35-57\% of energy) following a prolonged bout of endurance exercise restores intramuscular triacylglycerol more effectively than a low-fat diet (10-24\%) [107]. Thus, diets lacking adequate amounts of dietary fat can hinder the restoration of intramyocellular lipid stores following endurance exercise, and may negatively influence performance in subsequent exercise bouts [108]. Overall, females must consider adequate dietary fat intake to meet the increased reliance on fat oxidation. From a practical standpoint, females should allocate at least $20 \%$ of total energy to dietary fats, not only to meet the demands of sex hormone regulation and fat-soluble vitamin absorption, but also to satisfy sex-specific substrate needs. Additional emphasis should be placed on dietary fat intake during the luteal phase of the menstrual cycle to support the increased reliance on fat metabolism.

\section{Protein}

Dietary protein has many functions in the body with regulation of skeletal muscle mass being a primary role. Skeletal muscle is constantly evolving with a balance between breakdown (muscle protein breakdown [MPB]) and regeneration (muscle protein synthesis [MPS]) [109]. Maintaining adequate protein intake is paramount to ensure that the rate of MPS is at least equal to the rate of $\mathrm{MPB}$, and muscle mass is maintained. Amino acids are critically important since they are the building blocks for new proteins in the body, such as actin in skeletal muscle. Emphasis must be placed on obtaining adequate amounts of essential amino acids, which can only be obtained through food ingestion. Specifically, the essential amino acid leucine has been shown to stimulate MPS through indirect activation of the mammalian target of rapamycin (mTOR). Absence of leucine from the matrix may cause mTOR to enter a refractory period where stimulation via external signals is not possible [110]. The current recommended dietary allowance (RDA) of protein for all sedentary adults over the age of 18 years is $0.8 \mathrm{~g} / \mathrm{kg} /$ day. This number, however, is likely outdated and is based on the nitrogen balance method, which may not be as accurate as more recent techniques. It has also been suggested that this number is often misunderstood as an optimal level of protein intake rather than a minimal level to prevent muscle loss [111]. Humayun and colleges [112], found that a better baseline protein intake for sedentary men is likely $1.2 \mathrm{~g} / \mathrm{kg} /$ day. Additionally, females likely need higher protein intakes due to increased protein oxidation; a baseline starting point for women has been suggested to be $\sim 1.6 \mathrm{~g} /$ $\mathrm{kg} /$ day $[113,114]$, although more research is needed to fully understand protein requirements for females.

As previously mentioned, female sex hormones (estrogen and progesterone) peak during the mid-luteal phase, which corresponds to an increase in protein oxidation at rest $[115,116]$. It has been shown that females require more lysine during the luteal phase than the follicular 
Proposed Meal Plan: Female Soccer Player

Age: 20 years | Weight: $60 \mathrm{~kg}$ | Height: 5'5"

Energy Balance: 2,217-2,467 kcals | Goal Intake: 2,460-2,508 kcals

Performance Goal: This athlete is a collegiate soccer player who often experiences fatigue (muscle soreness). She wants to improve her endurance and sprint speed during the game by implementing nutritional strategies to promote performance and recovery.

Protein Goal: $480-528$ kcals $(\sim 20 \%)$ | Carbohydrate Goal: 1,440 kcals $(\sim 60 \%) \mid$ Fat Goal: 540 kcals $(\sim 20 \%)$

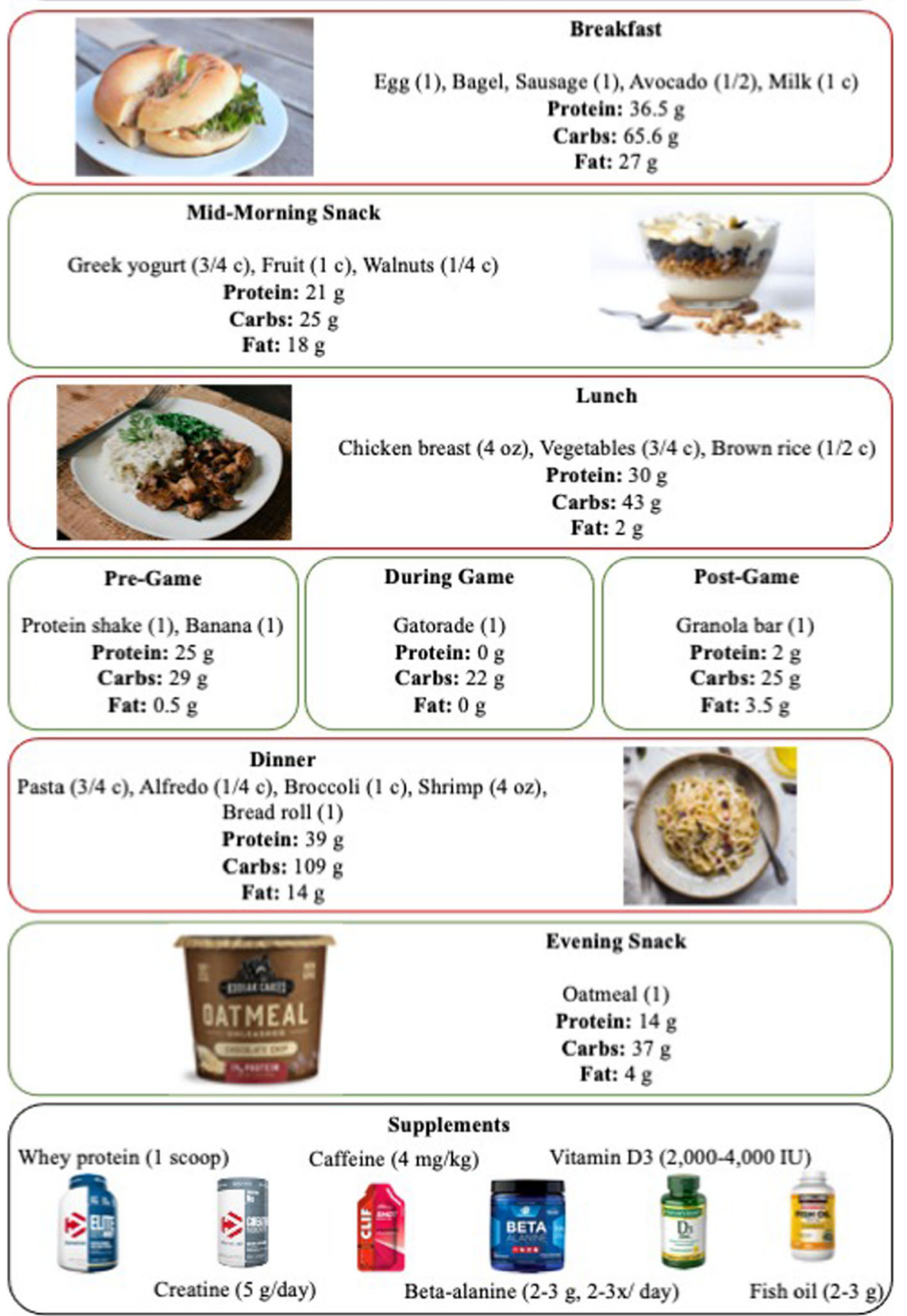

Fig. 3 (See legend on next page.) 
(See figure on previous page.)

Fig. 3 Application for a 20-year-old female who is a soccer player. She is $165.0 \mathrm{~cm}$ tall and currently weighs $60 \mathrm{~kg}$. She often experiences fatigue after a game (muscle soreness) and wants to improve her nutritional strategies to enhance performance (sprint speed and endurance). Using the Harris-Benedict equation, her basal metabolic rate (BMR) was determined to be approximately $1430 \mathrm{kcal} /$ day. Considering she is active, her total daily energy expenditure was estimated at approximately $2217-2467 \mathrm{kcal} /$ day by multiplying BMR by an activity coefficient of 1.55-1.725 (one soccer game). A possible macronutrient distribution for performance is $60 \%$ carbohydrates $(\sim 5.6 \mathrm{~g} / \mathrm{kg}), 20 \%$ protein $(\sim 1.9 \mathrm{~g} / \mathrm{kg})$, and $20 \%$ fat $(\sim$ $0.9 \mathrm{~g} / \mathrm{kg}$ ), which was utilized in the proposed meal plan for a game day

phase [31]. This is likely due to a number of reasons linked to progesterone upregulation of amino acid use. The spike in progesterone during the mid-luteal phase has been linked to a decrease in amino acid plasma levels, resulting from increased protein biosynthesis from endometrial thickening [116]. Further, protein use during exercise appears to be greater during the mid-luteal phase [117]. Increasing protein consumption is likely warranted during the mid-luteal phase to meet the anabolic demands of the body, especially when exercising.

When combined with resistance training, increased protein intake has a synergistic effect on increases in muscle strength and skeletal muscle mass (i.e. hypertrophy) [109]. For male bodybuilders, it has been shown that the estimated average requirement (EAR) and upper 95\% CI RDA (safe intake) for male bodybuilders is $\sim 1.7$ and $\sim 2.2 \mathrm{~g} / \mathrm{kg} /$ day, respectively [118]. This differs slightly from a study done in female strength athletes that suggests $\sim 1.5 \mathrm{~g} / \mathrm{kg} /$ day and $\sim 1.9 \mathrm{~g} / \mathrm{kg} /$ day for EAR and safe intake respectively [119]. However, a $\sim 60 \%$ increase from habitual protein intake may be needed to support skeletal muscle hypertrophy [120]. A study of female cyclists and triathletes (endurance athletes) showed that their mean protein requirement was $1.63 \mathrm{~g} / \mathrm{kg} /$ day, which corresponds with male counterpart recommendations [121]. However, an important consideration of this study is that women were tested during the midfollicular phase of the menstrual cycle. With increased protein oxidation in the luteal phase, protein needs may be further elevated. Menstrual cycle phase should be considered when evaluating dietary protein needs for females.

Simply meeting protein needs for a given day is important; the timing of protein ingestion must also be considered. A study by Areta and Colleagues [122], examined the influence of $80 \mathrm{~g}$ of whey protein isolate supplement ( $82.9 \mathrm{~g}$ of protein) during a 12-hour recovery following resistance exercise. Maximal MPS was achieved through intermediate feeding ( $20 \mathrm{~g}$ every $4 \mathrm{~h}$ verses) versus both pulse $(10 \mathrm{~g}$ every $1.5 \mathrm{~h})$ and bolus ( $40 \mathrm{~g}$ every $6 \mathrm{~h}$ ) feeding. Other studies have shown that consuming protein prior to exercise may increase muscle protein synthesis compared to post exercise [123]. A study including exclusively women demonstrated that consumption of fat-free milk (a complete animal protein) immediately and 1 -h post resistance exercise resulted in significant increases in strength and LM, coupled with a decrease in FM compared to women consuming an isoenergetic carbohydrate [124]. Upper body strength may also be influenced by nutrient timing, as one study found that trained females who consumed a 1:1.5 ratio carbohydrate: protein supplement $(16 \mathrm{~g}$ CHO: $25 \mathrm{~g}$ protein) either pre or post training significantly increased their bench press 1RM following a six week high intensity strength training program compared to no supplement [125]. Interestingly, this same study also demonstrated increased fat oxidation at 30-min post-exercise in the women who consumed the supplement pre-training. Another study by Wingfield and colleagues [126], may offer insight into this increased fat oxidation as they showed that pre-exercise protein ingestion increased REE and decreased RER at both 30- and 60-min following exercise compared to isocaloric $\mathrm{CHO}$ consumption. This study also assessed exercise modality and found that high intensity interval training (HIIT) yielded the greatest increase in REE and decrease in RER post-exercise, suggesting that a combination of preexercise protein consumption coupled with HIIT may have benefits for body composition and weight reduction in women. Increased dietary protein may also be beneficial when in a caloric or energy deficit (e.g. weight loss/ body recomposition). A recent review paper reported that high levels of dietary protein in women supports the maintenance of muscle mass and whole-body protein homeostasis during caloric deficit, but the beneficial effects of a high protein diet are decreased as the deficit increases [127]. Additionally, while in a caloric deficit, women who consumed more of their calories from PRO compared to $\mathrm{CHO}$ demonstrated an increase in the fat/ lean mass loss ratio resulting in a greater percentage of weight loss from FM while sparing LM [10].

Evidence suggests that females have increased daily protein needs well above the current RDA of $0.8 \mathrm{~g} / \mathrm{kg} /$ day. Female strength and endurance athletes should consume a minimum of $1.6 \mathrm{~g} / \mathrm{kg} /$ day. If hypertrophy is the goal, an additional $60 \%$ deviation from their habitual intake may be needed [120]. Spacing protein consumption throughout the day in 20-30-g servings to meet the daily requirement is more optimal compared to than one large bolus or smaller and frequent feedings. For weight loss, it is recommended that protein consumption be increased even further to ensure the majority of weight 
loss is FM, while LM is maintained. Resistance exercise may have a synergistic effect of maintaining muscle mass with a high protein diet during times of caloric deficit; as such females may consider implementing a resistance-based training program. Females should also consider cycle phase as there may be an increased demand for protein during the luteal phase. An example of how a woman may consider menstrual cycle phase into caloric and macronutrient needs is depicted in Fig. 4.

\section{Dietary supplements}

The majority of dietary supplements have been evaluated primarily in men; based on physiological theory and sexphysiology, the following sections introduce potential dietary supplements that may be efficacious for women. Table 1 outlines each supplement, potential implication for taking the supplement, and the dosage needed to be effective. Although there does not appear to be major sex-differences in the recommendations for dosages or

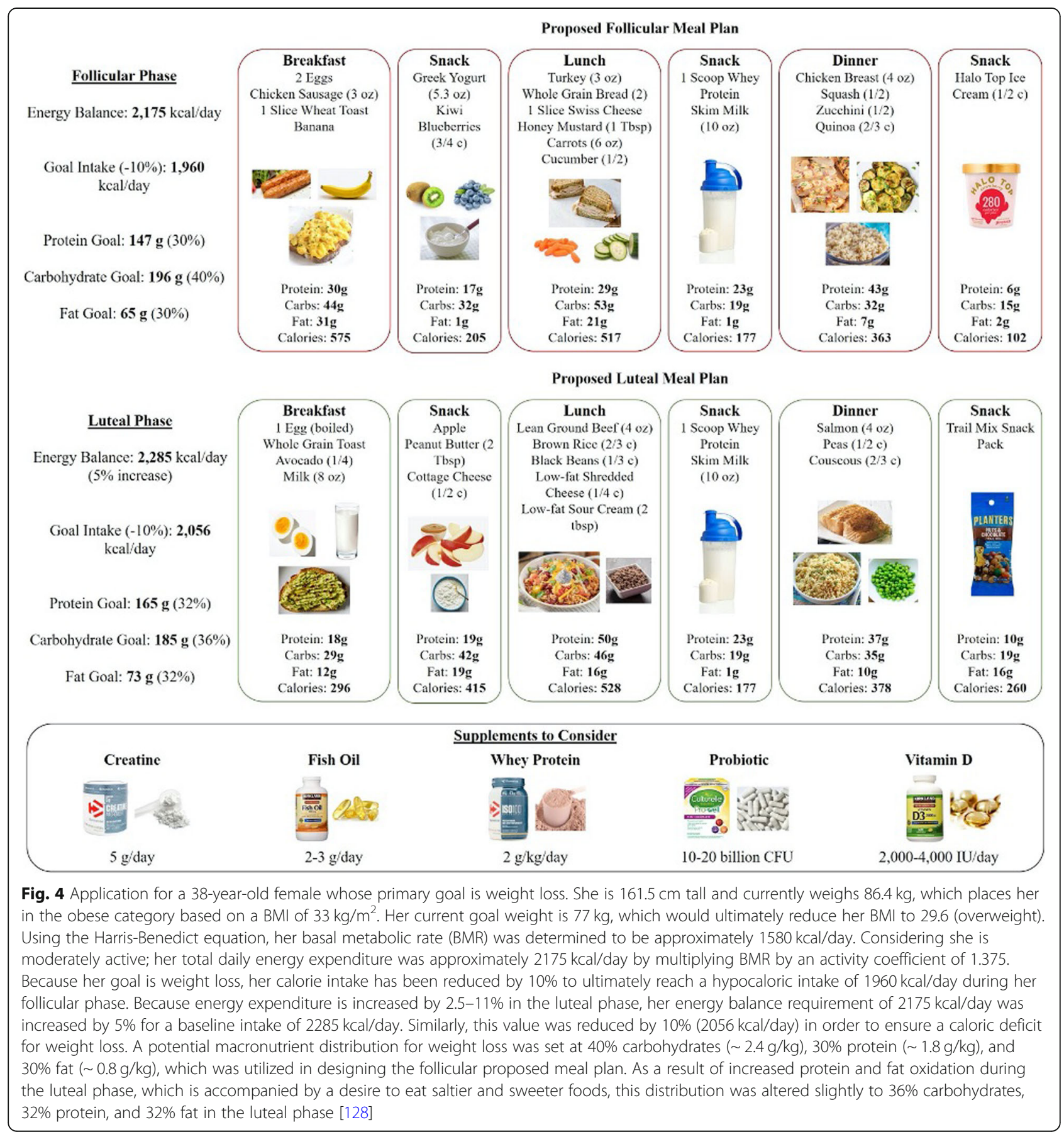


Table 1 Dietary supplements that may be beneficial for women

\begin{tabular}{|c|c|c|}
\hline Supplement & Purpose & Dose \\
\hline \multirow[t]{4}{*}{ Beta-alanine } & Enhance exercise performance & 4-6g/day in 1-2g divided doses for 4 wks \\
\hline & Acts as a buffer & \multirow{3}{*}{$\begin{array}{l}\text { A slower releasing supplement can increase skeletal muscle } \\
\text { carnosine levels more than a rapid releasing supplement }\end{array}$} \\
\hline & Fatigue attenuation & \\
\hline & Optimize recovery & \\
\hline \multirow[t]{3}{*}{ Caffeine } & Increase athletic performance & \multirow{3}{*}{$\begin{array}{l}\text { Doses between } 3-9 \mathrm{mg} / \mathrm{kg} / \text { allow ergogenic effects when } \\
\text { consumed } 60 \text { minutes before exercise }\end{array}$} \\
\hline & Spare glycogen by increasing fat metabolism & \\
\hline & Decrease pain perception & \\
\hline \multirow[t]{2}{*}{ Calcium } & Vital to muscle contraction and relaxation & \multirow[t]{2}{*}{ 1000mg/day } \\
\hline & Helpful for bone density & \\
\hline \multirow{9}{*}{$\begin{array}{l}\text { Creatine } \\
\text { Monohydrate }\end{array}$} & Enhance exercise performance & \multirow{4}{*}{$\begin{array}{l}0.3 \mathrm{~g} / \mathrm{kg} \text { of body weight } 4 \text { times a day for } 5 \text { to } 7 \text { days for a } \\
\text { "loading phase" }\end{array}$} \\
\hline & Decrease injury risk & \\
\hline & Enhance rehabilitation & \\
\hline & Decrease disease risk in young, middle aged, and old age groups & \\
\hline & Increased fat free mass & \multirow{5}{*}{$\begin{array}{l}\text { Followed by a "maintenance" phase where one where one } \\
\text { should ingest } 5 \mathrm{~g} / \text { day }\end{array}$} \\
\hline & $\begin{array}{l}\text { Effective during menses, pregnancy, and post-partum (regulate } \\
\text { mood and decrease depression) }\end{array}$ & \\
\hline & Beneficial to mental health & \\
\hline & Beneficial to bone health & \\
\hline & Neuroprotection & \\
\hline Folate & Decrease chance of anemia & 400ug/day \\
\hline Iron & Decrease chance of anemia & 18mg/day \\
\hline \multirow[t]{5}{*}{ Omega-3 } & Anti-inflammation & \multirow{5}{*}{$\begin{array}{l}\text { To see the benefits of omega-3, 1-3g should be consumed a } \\
\text { day }\end{array}$} \\
\hline & Decrease the overall risk of disease & \\
\hline & Plays a vital role in growth and development & \\
\hline & Improve immune function & \\
\hline & Decrease depression & \\
\hline \multirow[t]{5}{*}{ Probiotics } & Meet overall health needs & Consuming a multistrain probiotic \\
\hline & Regulate immune and digestive function & \multirow{4}{*}{$\begin{array}{l}\text { Probiotics taken daily should include } 10 \text { to } 20 \text { billion colony } \\
\text { forming units (CFU) }\end{array}$} \\
\hline & Regulate uro-genital tract & \\
\hline & Promote skin health & \\
\hline & Reduce inflammation & \\
\hline \multirow[t]{2}{*}{ Riboflavin } & Help skin & $1.1 \mathrm{mg} / \mathrm{day}$ \\
\hline & Regulate endocrine function & $1.6 \mathrm{mg}$ per 1000 calories (if exercising or lactating) \\
\hline Vitamin B12 & Decrease chance of anemia & 2.4ug/day \\
\hline Vitamin D3 & Promote bone health & 2,000 to $4,000 \mathrm{IU}$ is safe and beneficial \\
\hline \multirow[t]{6}{*}{ Whey Protein } & $\begin{array}{l}20-30 \mathrm{~g} \text { boluses throughout the day to reach the recommended } \\
1.6 \mathrm{~g} / \mathrm{kg} / \text { day for active women }\end{array}$ & \multirow[t]{6}{*}{$\begin{array}{l}20-30 \mathrm{~g} \text { boluses throughout the day to reach the recommended } \\
1.6 \mathrm{~g} / \mathrm{kg} / \text { day for active women }\end{array}$} \\
\hline & Improve body composition & \\
\hline & Increase bone mineral density & \\
\hline & Important to muscle protein synthesis & \\
\hline & Increase time to exhaustion during exercise & \\
\hline & Improve recovery & \\
\hline
\end{tabular}


usage of key dietary supplements; this summary aims to highlight supplements that have been studied in women and have been shown to be efficacious. Additionally, some of the supplements that have been discussed here appear to have a differential mechanistic effect (i.e. creatine) or notable points (i.e. half-life, timing, etc), for example. We must also recognize that the evaluation of dietary supplements in women needs additional attention; this section highlights ingredients that may be of particularly importance for active women.

\section{Beta-alanine}

Beta-alanine is a non-essential amino acid that enhances exercise performance through increasing muscle carnosine levels and acts as a hydrogen ion buffer, thereby lowering $\mathrm{pH}$ [129]. Increasing muscle carnosine has resulted in improvements in exercise performance lasting primarily 2-4 min [129]. While the majority of data with beta-alanine supplementation is in males, women have reported lower initial muscle carnosine levels, suggesting they could potentially see greater benefits compared to men [130]. Varanoske et al. [131] reported 28 days of beta-alanine supplementation was more effective for women, than men, for increasing muscle carnosine, although fatigue attenuation was similar for both men and women [131]. In a later study, Varanoske et al. [132] examined the influence of muscle carnosine levels of fatigue during resistance training and discovered that women who consumed more dietary protein had higher carnosine levels, those with higher carnosine levels, were able to delay fatigue longer than the women with lower carnosine levels. In a more recent paper [133], when selecting slow releasing or rapid releasing beta-alanine supplements, a slower releasing beta-alanine supplement taken $6 \mathrm{~g}$ per day for 28 days increased skeletal muscle carnosine levels by $16.4 \%$ more than consuming a rapid releasing supplement [133]. Individuals who suffer from low muscle carnosine levels such as older adults, women, and vegetarians could benefit from supplementing with beta-alanine [134]. Beta-alanine supplementation recommendations should not differ between men and women. Harris and company [135] showed that a total dose of 4-6g/day divided into $1-2 \mathrm{~g}$ doses for 4 weeks increases muscle carnosine concentrations by $64 \%$. Overall, beta-alanine may be effective for delaying fatigue and/or optimizing recovery in women. Of note, beta-alanine often results in a paresthesia or tingling side effect; this is harmless, and may actually be more prevalent in males vs. females [136].

\section{Caffeine}

Caffeine is a popular, natural ergogenic aid that causes physiological response by acting upon adenosine receptors and acts as a central nervous system stimulant
[137], please see ISSN Position Statement for extensive details on caffeine [138]. Caffeine elimination fluctuates over the course of the menstrual cycle, and some women feel the effects of caffeine longer during their luteal phase [139]. Previous literature shows women can accumulate caffeine during the luteal phase prior to beginning menstruation, and experience the effects of caffeine longer [139]. These effects can increase premenstrual symptoms in some women, as well as intensify normal effects of caffeine such as cardiovascular effects (i.e. heart rate), anxiety, and impaired sleep [139-141]. During anaerobic and aerobic exercise, caffeine can act as a ergogenic aid [142]. A resistance training study in women showed that caffeine $(6 \mathrm{mg} / \mathrm{kg})$ is effective for increasing strength performance and increasing bench press 1RM [143]. Caffeine has also been shown to effective for aerobic exercise performance as it spares muscle glycogen by increasing fat metabolism [142]. Caffeine has also been known to decrease pain perception which would be helpful prior to all types of exercise [142]. Doses between 3 and $9 \mathrm{mg} / \mathrm{kg}$ allow ergogenic effects when consumed 60 min before exercise [142]. Little evidence exists that would suggest a need for a different dose in women.

\section{Creatine monohydrate}

Previous studies have shown that creatine supplementation can improve athletic performance, decrease injury risk, enhance rehabilitation, and decrease disease risk in young, middle aged, and old age groups. Creatine works by increasing muscle phosphocreatine stores, which can increase energy availability $[144,145]$ (see ISSN position stand on creatine: [146]). When discussing nutrition for women, the menstrual cycle must be taken into consideration as hormonal changes occur across the cycle. Several studies acknowledge the gap in the literature involving female's supplementation with creatine and have found that creatine can be effective during menses, pregnancy, and post-partum. Also, as women age, creatine has been found to be beneficial for improving mental health, bone health, and physical function [147]. Although many studies highlight creatine's ability to enhance performance, creatine is also beneficial to overall health, specifically brain health. Creatine can help cognitive abilities, regulate mood, decrease depression, and offer neuroprotection, particularly in women [148]. Recent literature has shown that creatine supplementation can protect the brain from traumatic brain injuries (TBI) and help recover from TBI [148].

Although men appear to be more sensitive to creatine supplementation, improved athletic performance and increased fat free mass have been observed in both sexes $[147,149,150]$. Moreover, in a study looking at high intensity interval training (HIIT), males and females who 
consumed creatine monohydrate had increased peak and relative peak anaerobic cycling power, dorsiflexion maximal voluntary contraction (MVC) torque, and increased lactate [151]. Creatine supplementation also has been shown to improve mean strength and endurance during repeated contractions in women [152]. There are two effective strategies to increase creatine stores; 1 ) a loading phase which requires ingestion of $0.3 \mathrm{~g} / \mathrm{kg}$ of body weight four times a day for 5 to 7 days followed by a "maintenance" phase of $3-5 \mathrm{~g} /$ day, or 2 ) a daily $5 \mathrm{~g}$ dose. Note this dosing strategy takes longer to increase $\mathrm{Cr}$ stores $[149,153]$. These dosing strategies will allow for an increase in muscle creatine stores as well as the previously mentioned health benefits. One potential side effect from creatine supplementation is related to weight gain, related to an increase in total body water. Weight gain with creatine supplementation is more prevalent in men; for women, weight gain may be more likely during the luteal phase due to hormonally related fluid shifts [154]. However, this is likely to occur only with a loading dose.

\section{Omega 3}

Omega-3 plays a role in anti-inflammation within the body and has been shown to decrease the risk of disease [155]. The two most active eicosanoids derived from omega-3 are DHA (docosahexaenoic acid) and EPA (eicosapentaenoic acid). DHA and EPA play a vital role in growth and development as well as decreasing cytokines within the body and improving immune function [155]. Previous literature has shown that individuals who suffer from rheumatoid arthritis, inflammatory bowel disease, or asthma can see improvements in symptoms from supplementing with EPA and DHA [155]. Omega-3 is not only important for physical health, but also mental health as evidence shows that individuals who consume more omega-3 are less likely to be depressed [156]. Omega-3 fatty acids aid in growth and development as they are often supplemented during pregnancy with previous literature showing benefits for both the mother and infant [157]. Essential fats are also needed to counteract the Triad and RED-S, which were discussed previously. Women who over train and under consume calories can experience detrimental side effects, such as amenorrhea and loss of BMD [99]. Omega-3 supplementation may help to address the higher inflammatory response seen in women following exercise; increased omega-3 levels have also been shown to reduce symptoms of depression and anxiety, particularly in women. To see the benefits of omega-3, 1-3 g daily should be consumed [158].

\section{Probiotics}

Probiotics have become a popular dietary supplement [153]. They have been shown to improve the bacterial composition within the intestines, regulate immune and digestive function, and aid uro-genital tract and skin health [159] (see ISSN position statement for extended discussion: [160]). Previous research states that probiotic supplementation can improve intestinal function and reduce inflammation [161]. Probiotics can even be helpful in treating recurring urinary tract infections (UTIs) in some women [162]. A recent study relevant to females, demonstrated an improvement in iron levels and absorption when $20 \mathrm{mg}$ of iron (ferrous-fumarate) was combined with lactobaccilus plantarum 299v (LP299V, $10^{10}$ $\mathrm{CFU}$ ), suggesting this probiotic strain may help improve iron levels [163]. Probiotics should be chosen based on strain and desired outcome; strains may vary for women compared to men $[164,165]$. Consuming a multistrain probiotic supplement may be the most feasible way to experience these health benefits; additionally, being strategic in choosing a single strain would be beneficial based on the reported function of the specific strain. The probiotic supplement should be taken daily and should include 10 to 20 billion colony forming units (CFU) [166], or a clinically validated strain at effect doses [160].

\section{Protein supplementation}

Women could greatly benefit from protein supplementation to meet their daily protein needs, especially during the luteal phase of the menstrual cycle, which is marked by increased protein oxidation $[113,114]$. There are several popular protein supplements with evidence to support beneficial effects. These include collagen peptides, essential amino acids, plant-based proteins, and whey. Collagen peptides, when paired with resistance training, can improve body composition and increase muscle strength [167]. Additionally, collagen peptide supplementation increases bone formation while reducing bone degradation in postmenopausal women. This increase bone mineral density has been shown with a dosage of 5 $\mathrm{g} /$ day for one year [158]. It must be recognized that collagen protein is not a complete protein. This suggests that it is often more effective to consume a collagen protein with a complete protein (i.e. whey, EAA, dairy). Essential amino acids (EAAs) are important to muscle protein synthesis and can have ergogenic effects [168]. Previous literature has shown that six weeks of EAA supplementation (18.3 g/day) improves TTE, a measure of aerobic muscular endurance [168]. Additionally, consuming 6-12 $\mathrm{g}$ of EAA alone or in part of a protein supplement of $20-40 \mathrm{~g}$ can stimulate muscle protein synthesis [169]. Plant-based proteins have also become popular sources of protein supplementation and are 
usually seen as legume, nut, or soy protein [170]. Because of the amino acid profiles of the different plantbased sources, multiple types must be combined, or the addition of single amino acids, in order to adequately stimulate MPS [170, 171]. If consuming a plant-based protein, it is recommended to potentially increase the serving size or a probiotic as a way to enhance the amino acid absorption [172]. This technique ensures that enough leucine is consumed to stimulate MPS. Whey protein is the highest quality form of protein and is available as hydrolysate, isolate, and concentrate. Whey protein isolate is pure with protein concentration $>90 \%$ due to lactose and fat being removed [170] and may be most beneficial for women to prevent gastrointestinal distress. Previous data has supported the use of protein prior to and/or after exercise in women to enhance muscle recovery and LM [173].

\section{Vitamins and minerals}

The addition of supplemental vitamins and minerals can benefit highly active individuals. Female athletes that are menstruating may have an increased need for certain vitamins and minerals. Specifically, female athletes are often lacking in folate, riboflavin, and B12 [16]. Deficiencies in folate and B12 can cause anemia, which hampers athletic performance [174]. The average folate intake in women is $126-364 \mu \mathrm{g} /$ day. This measure is well below the current RDA of $400 \mu \mathrm{g} / \mathrm{day}$ [16]. Folate supplementation is a simple, effective method to meet current recommendations and avoid performance decrements. The RDA for Riboflavin is $1.1 \mathrm{mg} /$ day for women. Notably, this standard was established in 1998 [175] and may not reflect emerging research. Those deficient in Riboflavin can experience sore throats, hyperemia, swelling of the mouth and throat, and skin disorders [175, 176]. Riboflavin is usually $1.4 \mathrm{mg}$ per $1000 \mathrm{cal}$, but women exercising or lactating should consume $1.6 \mathrm{mg}$ per $1000 \mathrm{cal}$ [16, 175]. The RDA for B12 for adults is $2.4 \mu \mathrm{g} /$ day [175]. There are little known differences between men and women, but it is important for women who are pregnant and nursing to consume adequate doses of B12 to give to their child. Individuals following plant-based diets usually lack B12 as it is most commonly consumed from meat and the bioavailability is low in plants [177]. As mentioned previously, women who are lacking B12 can become anemic and feel fatigued faster when exercising [175]. In addition to lacking B vitamins, some individuals lack vitamin D as well. The RDA for Vitamin D is 600 IU for both men and women 9 to 70 years of age. Individuals over 70 years of age should increase consumption to $800 \mathrm{IU}$ [178]. Previous literature has shown that dosages of 2000 to $4000 \mathrm{IU}$ are safe and beneficial [178]. Vitamin D closely works with calcium to promote bone health. Those deficient in vitamin $\mathrm{D}$ can have poor mineralization of the bone and lead to skeletal disorders, especially as one ages [178].

Female athletes have lower calcium intakes when compared to their male counterparts. Additionally, those with dairy sensitivities are at an even greater risk for low calcium levels [16]. The daily recommended intake (DRI) of calcium for adult females is $1000 \mathrm{mg} /$ day [178]. Supplementation is a viable alternative for female athletes who do not consume dairy or who are under consuming calories [16]. Calcium is also vital to muscle contraction and relaxation; therefore, supplementation may promote optimal muscle function [178]. Iron deficiencies are extremely common among female athletes especially those that are vegan/vegetarian and under consuming calories. The ISSN recommends males consume $8 \mathrm{mg} /$ day, while women should consume $18 \mathrm{mg} /$ day [153].

\section{Conclusions and practical applications}

Emerging evidence underscores the importance of sex specific nutritional strategies and recommendations for females, particularly active females. Key physiological differences between the sexes are brought about by differences in sex hormone concentrations; however, intraindividual differences also exist in females, throughout the menstrual cycle and throughout the lifecycle (i.e. puberty, pregnancy, menopause). These differences occur during phases of the menstrual cycle, which are due to fluctuating hormonal levels, for example increased estrogen and progesterone during the mid-luteal phase [25]. Because of this, females may benefit from separate sex specific nutritional recommendations, especially when engaging in regular exercise. Specific caloric, macronutrient, micronutrient, and supplement recommendations should be tailored to the individual to meet their desired goals, but basic requirements and staring points are likely universal, and thus addressed within this review. Further, timing and dosing must be considered, especially when performance or recovery are primary goals. These distinct nutritional guidelines and recommendations for females are warranted given the sex-based difference but have been lacking to date. There is also a significant lack of studies assessing female specific nutritional strategies for health, performance, and body composition. Future additional research evaluating female specific nutritional strategies is needed, especially for active women.

\footnotetext{
Abbreviations

\%fat: Body fat percentage; 1RM: One repetition maximum; AMDR: Acceptable macronutrient distribution range; BMD: Bone mineral density; CK: Creatine kinase; DHA: Docosahexaenoic acid; EAA: Essential amino acids; EAR: Estimated average requirement; EPA: Eicosapentaenoic acid; FFA: Free fatty acids; FM: Fat mass; FSH: Follicle stimulating hormone; HIIT: High intensity interval training; IL-6: Interleukin-6; LH: Luteinizing hormone; LM: Lean mass; MPB: Muscle protein breakdown; MPS: Muscle protein
} 
synthesis; mTOR: Mammalian target of rapamycin; MVC: Maximal voluntary contraction; RDA: Recommended dietary allowance; RED-S: Relative energy deficiency in sport; REE: Resting energy expenditure; RER: Respiratory exchange ratio; TBI: Traumatic brain injury; TEE: Time to exhaustion; Triad: Female athlete triad

\section{Acknowledgments}

Not applicable.

\section{Authors' contributions}

$\mathrm{KW}, \mathrm{LA}$, and ASR were major contributors to writing and formatting the document. $L G, G B, A H$ contributed to writing the manuscript. All authors read and approved the final manuscript.

\section{Funding}

Not applicable.

\section{Availability of data and materials}

Not applicable.

\section{Declarations}

\section{Ethics approval and consent to participate}

Not applicable.

\section{Consent for publication}

Not applicable.

\section{Competing interests}

ASR has received research funding from government and industry sponsors to evaluate dietary supplements; ASR serves as a scientific advisor for Alzchem, Ladder Sport, and Hologic Inc.

Received: 22 December 2020 Accepted: 12 March 2021

Published online: 01 April 2021

\section{References}

1. UN. Women, gender equality and sport. Women 2000 Beyond. 2007:1-40.

2. Fink JS. Female athletes, women's sport, and the sport media commercial complex: Have we really "come a long way, baby"? Sport Manag. Rev. 2015: 331-42.

3. McNulty KL, Elliott-Sale KJ, Dolan E, Swinton PA, Ansdell P, Goodall S, et al. The Effects of Menstrual Cycle Phase on Exercise Performance in Eumenorrheic Women: A Systematic Review and Meta-Analysis. Sport Med [Internet]. Springer International Publishing; 2020; Available from: https://doi. org/10.1007/s40279-020-01319E-3.

4. Benton MJ, Hutchins AM, Dawes JJ. Effect of menstrual cycle on resting metabolism: A systematic review and metaanalysis. PLoS One. Public Library of Science; 2020 [cited 2020 4];15. Available from: https://pubmed.ncbi.nlm. nih.gov/32658929/

5. Corella $\mathrm{D}$, Coltell $\mathrm{O}$, Portolés $\mathrm{O}$, Sotos-Prieto M, Fernández-Carrión $\mathrm{R}$, Ramirez-Sabio JB, et al. A guide to applying the sex-gender perspective to nutritional genomics [Internet]. Nutrients. MDPI AG; 2019 [cited 2020 Oct 4]. Available from: https://pubmed.ncbi.nlm.nih.gov/30577445/

6. Roepstorff C, Steffensen CH, Madsen M, Stallknecht B, Kanstrup IL, Richter EA, et al. Gender differences in substrate utilization during submaximal exercise in endurance-trained subjects. Am J Physiol. 2002;282:435-47.

7. Campbell SE, Angus DJ, Febbraio MA. Glucose kinetics and exercise performance during phases of the menstrual cycle: effect of glucose ingestion. Am J Physiol. 2001;281:817-25.

8. Gorczyca AM, Sjaarda LA, Mitchell EM, Perkins NJ, Schliep KC, WactawskiWende J, et al. Changes in macronutrient, micronutrient, and food group intakes throughout the menstrual cycle in healthy, premenopausal women. Eur J Nutr. 2016;55:1181-8 Available from: http://www.ncbi.nlm.nih.gov/ pubmed/26043860 [cited 202015 Apr].

9. Walker JL, Heigenhauser GJF, Hultman E, Spriet LL. Dietary carbohydrate, muscle glycogen content, and endurance performance in well-trained women. J Appl Physiol. 2000;88(6):2151-8. https://doi.org/10.1152/jappl.2 000.88.6.2151.

10. Layman DK, Boileau RA, Erickson DJ, Painter JE, Shiue H, Sather C, et al. A Reduced Ratio of Dietary Carbohydrate to Protein Improves Body
Composition and Blood Lipid Profiles during Weight Loss in Adult Women. Jutr. 2003:133, 411-7 Available from: https://academic.oup.com/jn/a rticle-abstract/133/2/411/4687883 [cited 202013 Apr].

11. Kerksick CM, Wilborn CD, Roberts MD, Smith-Ryan A, Kleiner SM, Jäger R, et al. ISSN exercise \& sports nutrition review update: Research \& recommendKerksick, C. M., Wilborn, C. D., Roberts, M. D., Smith-Ryan, A., Kleiner, S. M., Jäger, R., ... Kreider, R. B. (2018). ISSN exercise \& sports nutrition review update: Research \& recommendat. J Int Soc Sports Nutr. 2018;15:1-57.

12. Jonason PK. An evolutionary psychology perspective on sex differences in exercise behaviors and motivations. J Soc Psychol. 2007;147:5-14 Available from: https://www.tandfonline.com/doi/abs/10.3200/SOCP.147.1.5-14 [cited 202025 Sep].

13. Silberstein LR, Striegel-Moore RH, Timko C, Rodin J. Behavioral and psychological implications of body dissatisfaction: Do men and women differ? Sex Roles; 1988; 19: 219-232. Available from: https://link.springer. com/article/10.1007/BF00290156 [cited 202025 Sep]

14. Shriver LH, Betts NM, Wollenberg G. Dietary intakes and eating habits of college athletes: are female college athletes following the current sports nutrition standards? J am Coll heal. 2013;

15. Hoogenboom BJ, Morris J, Morris C, Schaefer K. Nutritional knowledge and eating behaviors of female, collegiate swimmers. N Am J Sports Phys Ther. 2009.

16. Manore MM. Dietary recommendations and athletic menstrual dysfunction. Sport Med. 2002;32(14):887-901. https://doi.org/10.2165/00007256-20023214 0-00002.

17. Nattiv A, Loucks AB, Manore MM, Sanborn CF, Sundgot-Borgen J, Warren MP. The female athlete triad. Med Sci Sports Exerc. 2007;

18. Roepstorff C, Steffensen CH, Madsen M, Stallknecht B, Kanstrup IL, Richter EA, et al. Gender differences in substrate utilization during submaximal exercise in endurance-trained subjects. Am J Physiol. 2002;282(2):E435-47. https://doi.org/10.1152/ajpendo.00266.2001.

19. Pivarnik JM, Marichal CJ, Spillman T, Morrow JR. Menstrual cycle phase affects temperature regulation during endurance exercise. J Appl Physiol. 1992;72(2):543-8. https://doi.org/10.1152/jappl.1992.72.2.543.

20. Hunter SK. Sex differences in fatigability of dynamic contractions. Exp Physiol. 2016;101:250-5 Available from: https://www.ncbi.nlm.nih.gov/ pubmed/26440505 [cited 20208 Apr].

21. Hackney AC, Kallman AL, Ağgön E. Female sex hormones and the recovery from exercise: menstrual cycle phase affects responses. Biomed Hum Kinet. 2019;11(1):87-9. https://doi.org/10.2478/bhk-2019-0011.

22. Bredella MA. Sex differences in body composition. Adv Exp Med Biol. 2017: 9-27 Available from: https://www.ncbi.nlm.nih.gov/pubmed/29224088 [cited $202013 \mathrm{Apr}$.

23. Aucouturier J, Baker JS, Duché P. Fat and carbohydrate metabolism during submaximal exercise in children. Sport Med. 2008:213-38.

24. Isacco L, Duch P, Boisseau N. Influence of hormonal status on substrate utilization at rest and during exercise in the female population. Sport Med. 2012;42(4):327-42. https://doi.org/10.2165/11598900-000000000-00000.

25. Oosthuyse T, Bosch AN. The effect of the menstrual cycle on exercise metabolism: implications for exercise performance in eumenorrhoeic women. Sports Med. 2010;40:207-27 Available from: http://www.ncbi.nlm. nih.gov/pubmed/20199120 [cited 202020 Mar].

26. Lebrun CM. The effect of the phase of the menstrual cycle and the birth control pill on athletic performance. Clin Sports Med. 1994:419-41.

27. Reilly T. The Menstrual Cycle and Human Performance: An Overview. https:/doi. org/101076/0929-1016(200002)31:1;1-0;FT029. Taylor \& Francis Group ; 2010;

28. Van Pelt RE, Gavin KM, Kohrt WM. Regulation of Body Composition and Bioenergetics by Estrogens. Endocrinol Metab Clin North Am. 2015:663-76.

29. Davidsen L, Vistisen B, Astrup A, et al. Int J Obes. 2007:1777-85.

30. Bisdee JT, James WPT, Shaw MA. Changes in energy expenditure during the menstrual cycle. Br J Nutr. 1989:61:187-99.

31. Kriengsinyos W, Wykes LJ, Goonewardene LA, Ball RO, Pencharz PB. Phase of menstrual cycle affects lysine requirement in healthy women. Am J Physiol Endocrinol Metab. 2004;287:E489-96 Available from: https://www.ncbi.nlm. nih.gov/pubmed/15308475 [cited 202020 Mar].

32. Draper CF, Duisters K, Weger B, Chakrabarti A, Harms AC, Brennan L, et al. Menstrual cycle rhythmicity: metabolic patterns in healthy women. Sci Rep. 2018;8:14568 Available from: http://www.ncbi.nlm.nih.gov/pubmed/302754 58 [cited 202020 Mar].

33. Tarnopolsky MA. Gender differences in substrate metabolism during endurance exercise. Can J Appl Physiol. 2000;25:312-27. 
34. Blaak E. Gender differences in fat metabolism. Curr Opin Clin Nutr Metab Care. 2001:499-502.

35. Tiller NB, Elliott-Sale KI, Knechtle B, Wilson PB, Roberts JD, Millet GY. Do Sex Differences in Physiology Confer a Female Advantage in Ultra-Endurance Sport? [Internet]. Sport. Med. Springer Science and Business Media Deutschland GmbH; 2021 [cited 2021 Feb 5]. Available from: https:// pubmed.ncbi.nlm.nih.gov/33502701/

36. Lavoie JM, Dionne N, Helie R, Brisson GR. Menstrual cycle phase dissociation of blood glucose homeostasis during exercise. J Appl Physiol. 1987;62:10849 Available from: http://www.ncbi.nlm.nih.gov/pubmed/3571066 [cited 2020 $20 \mathrm{Mar}$.

37. Nicklas BJ, Hackney AC, Sharp RL. The menstrual cycle and exercise: performance, muscle glycogen, and substrate responses. Int I Sports Med. 1989;10(04):264-9. https://doi.org/10.1055/s-2007-1024913.

38. JEH J, Jones NL, Toews CJ, Sutton JR. Effects of menstrual cycle on blood lactate, $\mathrm{O} 2$ delivery, and performance during exercise. J Appl Physiol Respir Environ Exerc Physiol. 1981;51:1493-9 Available from: https://journals. physiology.org/doi/abs/10.1152/jappl.1981.51.6.1493 [cited 20205 Oct]

39. Smekal G, Von Duvillard SP, Frigo P, Tegelhofer T, Pokan R, Hofmann P, et al. Menstrual cycle: No effect on exercise cardiorespiratory variables or blood lactate concentration. Med Sci Sports Exerc; 2007; 39: 1098-1106. Available from: https://pubmed.ncbi.nlm.nih.gov/17596777/ [cited 20205 Oct]

40. Lebrun CM, McKenzie DC, Prior JC, Taunton JE. Effects of menstrual cycle phase on athletic performance. Med Sci Sports Exerc. 1995;27(3):437-44.

41. Casazza GA, Suh SH, Miller BF, Navazio FM, Brooks GA. Effects of oral contraceptives on peak exercise capacity. J Appl Physiol. 2002;93(5):1698702. https://doi.org/10.1152/japplphysiol.00622.2002.

42. Romero-Moraleda B, Del Coso J, Gutiérrez-Hellín J, Ruiz-Moreno C, Grgic J, Lara B. The influence of the menstrual cycle on muscle strength and power performance. J Hum Kinet Sciendo. 2019;68(1):123-33. https://doi.org/10.24 78/hukin-2019-0061

43. Miller AEJ, MacDougall JD, Tarnopolsky MA, Sale DG. Gender differences in strength and muscle fiber characteristics. Eur J Appl Physiol Occup Physiol. 1993;66(3):254-62. https://doi.org/10.1007/BF00235103.

44. Yoon T, Doyel R, Widule C, Hunter SK. Sex differences with aging in the fatigability of dynamic contractions. Exp Gerontol; 2015; 70:1-10. Available from: https://www.ncbi.nlm.nih.gov/pubmed/26159162 [cited 202013 Apr]

45. Ansdell P, Thomas K, Hicks KM, Hunter SK, Howatson G, Goodall S. Physiological sex differences affect the integrative response to exercise: acute and chronic implications. Exp Physiol; 2020. p. 2007-2021. Available from: https://pubmed.ncbi.nlm.nih.gov/33002256/ [cited 20215 Feb]

46. Bar-Or O. Effects of age and gender on sweating pattern during exercise. Int J Sports Med. 1998; 19 Suppl 2:S106-S107. Available from: https://www.ncbi. nlm.nih.gov/pubmed/9694411 [cited 20208 Apr]

47. Grucza R. Efficiency of thermoregulatory system in man under endogenous and exogenous heat loads. Acta Phys Pol A. 1990;41:123-45.

48. Kaciuba-Uscilko H, Grucza R. Gender differences in thermoregulation. Curr Opin Clin Nutr Metab Care. 2001:533-6.

49. Grucza R, Pekkarinen H, Titov EK, Kononoff A, Hänninen O. Influence of the menstrual cycle and oral contraceptives on thermoregulatory responses to exercise in young women. Eur J Appl Physiol Occup Physiol. 1993;67(3):27985. https://doi.org/10.1007/BF00864229.

50. Inoue Y, Tanaka Y, Omori K, Kuwahara T, Ogura Y, Ueda H. Sex- and menstrual cycle-related differences in sweating and cutaneous blood flow in response to passive heat exposure. Eur J Appl Physiol. 2005; 94: 323-332. Available from: https://www.ncbi.nlm.nih.gov/pubmed/15729550 [cited 2020 $8 \mathrm{Apr}]$

51. Redman LM, Heilbronn LK, Martin CK, Alfonso A, Smith SR, Ravussin E. Effect of calorie restriction with or without exercise on body composition and fat distribution. J Clin Endocrinol Metab; 2007; 92: 865-872. Available from: https://pubmed.ncbi.nlm.nih.gov/17200169/ [cited 202016 Nov]

52. Sartorio A, Maffiuletti NA, Agosti F, Lafortuna CL. Gender-related changes in body composition, muscle strength and power output after a short-term multidisciplinary weight loss intervention in morbid obesity. J Endocrinol Invest; 2005; 28: 494-501. Available from: https://pubmed.ncbinlm.nih.gov/1 6117189/[cited 202016 Nov]

53. Pearson AG, Alexander $L$, Witard OC, Coughlin TE, Tipton KD, Walshe $\mathbb{H}$. A hypoenergetic diet with decreased protein intake does not reduce lean body mass in trained females. Eur J Appl Physiol; 2020; 1-11. Available from: https://doi.org/10.1007/s00421-020-04555-7, 121, 3, 771, 781 [cited 202016 Dec]
54. Valentine RJ, Misic MM, Rosengren KS, Woods JA, Evans EM. Sex impacts the relation between body composition and physical function in older adults. Menopause; 2009; 16: 518-523. Available from: /pmc/articles/PMC2844341/ ?report=abstract [cited $202016 \mathrm{Nov}$ ]

55. Blunt BA, Klauber MR, Barrett-Connor EL, Edelstein SL. Sex differences in bone mineral density in 1653 men and women in the sixth through tenth decades of life: the Rancho Bernardo Study. J Bone Miner Res. 1994; 9 : 1333-1338. Available from: https://www.ncbi.nlm.nih.gov/pubmed/7817816 [cited 2020 Apr 13]

56. Lee N, Wingo P, Gwin M, Rubin G, Kendrick J, Webster L, et al. The Reduction in Risk of Ovarian Cancer Associated with Oral-Contraceptive Use. N Engl J Med; 1987; 316: 650-655. Available from: https://www.nejm.org/ doi/full/10.1056/NEJM198703123161102 [cited 2020 Dec 3]

57. Frye CA. An overview of oral contraceptives: Mechanism of action and clinical use [Internet]. Neurology. Lippincott Williams and Wilkins; 2006. Available from: https://pubmed.ncbinlm.nih.gov/16567739/ [cited 20203 Dec]

58. Daniels $\mathrm{K}$, Abma J. Current contracpetive status among women aged 15-49 [Internet]. NCHS Data Brief, no 327. 2018 [cited 2020 Dec 3]. Available from: https:/www.cdc.gov/nchs/products/databriefs/db327.htm

59. Hackney AC. Sex hormones, exercise and women. 2017, DOl: https://doi. org/10.1007/978-3-319-44558-8.

60. Van Vliet HA, Grimes DA, Helmerhorst FM, Schulz KF, Lopez LM. Biphasic versus monophasic oral contraceptives for contraception. Cochrane Database Syst Rev [Internet]. Wiley; 2006 [cited 2020 Nov 20];2006. Available from: /pmc/articles/PMC6492366/?report=abstract.

61. Van Vliet HA, Grimes DA, Lopez LM, Schulz KF, Helmerhorst FM. Triphasic versus monophasic oral contraceptives for contraception. Cochrane Database Syst Rev [Internet]. Wiley; 2011 [cited 2020 Dec 3];2011. Available from: /pmc/articles/PMC7154342/?report=abstract.

62. Godsland IF, Crook D, Simpson R, Proudler T, Felton C, Lees B, et al. The Effects of Different Formulations of Oral Contraceptive Agents on Lipid and Carbohydrate Metabolism. N Engl J Med; 1990; 323: 1375-1381. Available from: https://www.nejm.org/doi/full/10.1056/nejm199011153232003 [cited 2020 Dec 3]

63. van der Vange N, Kloosterboer HJ, Haspels AA. Effect of seven low-dose combined oral contraceptive preparations on carbohyrate metabolism. Am J Obstet Gynecol. 1987;156(4):918-22. https//doi.org/10.1016/0002-9378(87)90355-3.

64. Suh SH, Casazza GA, Horning MA, Miller BF, Brooks GA. Effects of oral contraceptives on glucose flux and substrate oxidation rates during rest and exercise. J Appl Physiol; 2003; 94: 285-294. Available from: https://pubmed. ncbi.nlm.nih.gov/12391078/ [cited 20203 Dec]

65. Silva-Bermudez LS, Toloza FJK, Perez-Matos MC, de Souza RJ, Banfield L, VargasVillanueva A, et al. Effects of oral contraceptives on metabolic parameters in adult premenopausal women: A meta-analysis. Endocr Connect. 2020;9:978-98 Available from: https:/pubmed.ncbi.nlm.nih.gov/33048062/ [cited 20203 Dec].

66. Casazza GA, Jacobs KA, Suh SH, Miller BF, Horning MA, Brooks GA. Menstrual cycle phase and oral contraceptive effects on triglyceride mobilization during exercise. J Appl Physiol. 2004;97:302-9 Available from: https:// pubmed.ncbi.nIm.nih.gov/14990561/ [cited 20203 Dec].

67. Larsen B, Cox A, Colbey C, Drew M, McGuire H, Fazekas de St Groth B, et al. Inflammation and Oral Contraceptive Use in Female Athletes Before the Rio Olympic Games. Front Physiol. 2020;11:497 Available from: https:/www. frontiersin.org/article/10.3389/fphys.2020.00497/full [cited 20203 Dec].

68. Cauci S, Francescato MP, Curcio F. Combined Oral Contraceptives Increase High-Sensitivity C-Reactive Protein but Not Haptoglobin in Female Athletes. Sport Med. 2017;47:175-85 Available from: https://pubmed.ncbi.nlm.nih. gov/27084393/ [cited 20203 Dec].

69. Rechichi C, Dawson B, Goodman C. Oral contraceptive phase has no effect on endurance test. Int J Sports Med. 2008;29:277-81 Available from: https:// pubmed.ncbi.nlm.nih.gov/17990209/ [cited 20203 Dec].

70. Rechichi C, Dawson B. Oral contraceptive cycle phase does not affect 200-m swim time trial performance. J Strength Cond Res; 2012 ; 26: 961-967. Available from: https:/pubmed.ncbi.nlm.nih.gov/22446669/ [cited 20203 Dec]

71. Lebrun CM, Petit MA, McKenzie DC, Taunton JE, Prior JC. Decreased maximal aerobic capacity with use of a triphasic oral contraceptive in highly active women: A randomised controlled trial. Br I Sports Med; 2003; 37: 315-320. Available from: https://pubmed.ncbi.nlm.nih.gov/12893716/ [cited 20203 Dec]

72. Dalgaard LB, Dalgas U, Andersen JL, Rossen NB, Møller AB, StødkildeJørgensen $\mathrm{H}$, et al. Influence of Oral Contraceptive Use on Adaptations to 
Resistance Training. Front Physiol; 2019; 10: 824. Available from: https:// www.frontiersin.org/article/10.3389/fphys.2019.00824/full [cited 20203 Dec]

73. Barrack MT, Gibbs JC, De Souza MJ, Williams NI, Nichols JF, Rauh MJ, et al. Higher incidence of bone stress injuries with increasing female athlete triadrelated risk factors: A prospective multisite study of exercising girls and women. Am J Sports Med. 2014;42:949-58 Available from: https://pubmed. ncbi.nlm.nih.gov/24567250/ [cited 20208 Nov]

74. Loucks $A B$, Thuma JR. Luteinizing hormone pulsatility is disrupted at a threshold of energy availability in regularly menstruating women. J Clin Endocrinol Metab. 2003;88(1):297-311. https://doi.org/10.1210/jc.2002-0203 69.

75. Loucks AB, Kiens B, Wright HH. Energy availability in athletes. J. Sports Sci. 2011.

76. Melin A, Tornberg ÅB, Skouby S, Faber J, Ritz C, Sjödin A, et al. The LEAF questionnaire: A screening tool for the identification of female athletes at risk for the female athlete triad. Br J Sports Med. 2014;48:540-5 Available from: https://pubmed.ncbi.n/m.nih.gov/24563388/ [cited 20208 Nov].

77. Williams NI, Koltun KJ, Strock NCA, De Souza MJ. Female athlete triad and relative energy deficiency in sport: A focus on scientific rigor. Exerc Sport Sci Rev. 2019:197-205 Available from: https://pubmed.ncbi.nlm.nih.gov/31 524785/ [cited 20208 Nov].

78. Benson JE, Engelbert-Fenton KA, Eisenman PA. Nutritional aspects of amenorrhea in the female athlete triad. Int J Sport Nutr Exerc Metab. 1996; 6(2):134-45. https://doi.org/10.1123/ijsn.6.2.134.

79. Otis CL, Drinkwater B, Johnson M, Loucks A, Wilmore J. American College of Sports Medicine position stand. The Female Athlete Triad. Med Sci Sports Exerc. 1997;

80. Mountjoy M, Sundgot-Borgen J, Burke L, Carter S, Constantini N, Lebrun C, et al. The IOC consensus statement: Beyond the Female Athlete TriadRelative Energy Deficiency in Sport (RED-S). Br J Sports Med; 2014; 48: 491497. Available from: https://pubmed.ncbi.nlm.nih.gov/24620037/ [cited 2020 8 Nov]

81. Henry CJK, Lightowler HJ, Marchini J. Intra-individual variation in resting metabolic rate during the menstrual cycle. Br J Nutr. 2003;89(6):811-7. https://doi.org/10.1079/BJN2003839.

82. Institute of Medicine. Dietary Reference Intakes For Energy, Carbohydrate, Fiber, Fat, Fatty Acids, Cholesterol, Protein, and Amino Acids. Natl Acad Press. 2002:335-432

83. Nutrition and Athletic Performance. Med Sci Sport Exerc [Internet]. Lippincott Williams and Wilkins; 2009 [cited 2020 Nov 16];41:709-31. Available from: http://journals.Iww.com/00005768-200903000-00027

84. Burke LM, Hawley JA, Wong SHS, Jeukendrup AE. Carbohydrates for training and competition. J Sports Sci. 2011;29(sup 1):S17-27. https://doi.org/10.1 080/02640414.2011.585473.

85. Hargreaves M, Hawley JA, Jeukendrup A. Pre-exercise carbohydrate and fat ingestion: effects on metabolism and performance. J Sports Sci. 2004;22(1): 31-8. https://doi.org/10.1080/0264041031000140536.

86. Wismann J, Willoughby D. Gender differences in Carbohydrate metabolism and Carbohydrate loading. J Int Soc Sports Nutr. 2006;3(1):28-34. https://doi. org/10.1186/1550-2783-3-1-28.

87. Bergstrom J. Diet, Muscle Glycogen. Acta Physiol Scand. 1967:140-50.

88. Burke LM, Kiens B, IVy JL. Carbohydrates and fat for training and recovery. J Sports Sci. 2004;22(1):15-30. https://doi.org/10.1080/0264041031000140527.

89. Tarnopolsky MA, Atkinson SA, Phillips SM, MacDougall JD. Carbohydrate loading and metabolism during exercise in men and women. J Appl Physiol. 1995;78(4):1360-8. https://doi.org/10.1152/jappl.1995.78.4.1360.

90. James A, Lorraine M, Cullen D, Goodman C, Dawson B, Palmer N, et al. Muscle glycogen supercompensation: absence of a gender-related difference. Eur J Appl Physiol. 2001;85(6):533-8. https://doi.org/10.1007/s004210100499.

91. Coyle EF, Coggan AR, Hemmert MK, Lowe RC, Walters TJ. Substrate usage during prolonged exercise following a preexercise meal. J Appl Physiol. 1985;59(2):429-33. https://doi.org/10.1152/jappl.1985.59.2.429.

92. Sherman W, Brodowicz G, Wright D, Allen W, Simonsen J, Dernbach A. Effects of $4 \mathrm{~h}$ preexercise carbohydrate feedings on cycling performance. Med Sci Sports Exerc. 1989;21(5):598-604.

93. Wright DA, Sherman WM, Dernbach AR. Carbohydrate feedings before, during, or in combination improve cycling endurance performance. J Appl Physiol. 1991;71(3):1082-8. https://doi.org/10.1152/jappl.1991.71.3.1082.

94. Bailey SP, Zacher CM, Mittleman KD. Effect of menstrual cycle phase on carbohydrate supplementation during prolonged exercise to fatigue. J Appl Physiol. 2000;88(2):690-7. https://doi.org/10.1152/jappl.2000.88.2.690.
95. Coyle EF. Fluid and fuel intake during exercise. J Sports Sci. 2004;22(1):3955. https://doi.org/10.1080/0264041031000140545.

96. Kerksick CM, Arent S, Schoenfeld BJ, Stout JR, Campbell B, Wilborn CD, et al. International society of sports nutrition position stand: Nutrient timing. J Int Soc Sports Nutr. 2017;14:1-21.

97. Tarnopolsky MA, Bosman M, MacDonald JR, Vandeputte D, Martin J, Roy BD. Postexercise protein-carbohydrate and carbohydrate supplements increase muscle glycogen in men and women. J Appl Physiol. 1997;83(6):1877-83. https://doi.org/10.1152/jappl.1997.83.6.1877.

98. Ivy JL. Glycogen Resynthesis After Exercise: Effect of Carbohydrate Intake. Int J Sports Med [Internet]. 1998; 142-145. Available from: https://www.sportsci. org/encyc/drafts/Glycogen.doc

99. Volek JS, Forsythe CE, Kraemer WJ. Nutritional aspects of women strength athletes. Br J Sports Med. 2006;40(9):742-8. https://doi.org/10.1136/bjsm.2 004.016709.

100. Kerksick CM, Wilborn CD, Roberts MD, Smith-Ryan A, Kleiner SM, Jäger R, et al. ISSN exercise \& sports nutrition review update: Research \& recommendations. J Int Soc Sports Nutr. 2018:1-57.

101. Simopoulos AP. The Mediterranean diets in health and disease. Am J Clin Nutr. 1991;54(4):771. https://doi.org/10.1093/ajcn/54.4.771.

102. Isacco L, Duch P, Boisseau N. Influence of hormonal status on substrate utilization at rest and during exercise in the female population. Sport Med. 2012:327-42.

103. Ruby B, Robergs R. Gender differences in substrate utilization during exercise. Sport Med. 1994;17(6):393-410. https://doi.org/10.2165/00007256-1 99417060-00005.

104. Hackney AC, McCracken-Compton MA, Ainsworth B. Substrate responses to submaximal exercise in the midfollicular and midluteal phases of the menstrual cycle. Int J Sport Nutr. 1994;4(3):299-308. https://doi.org/10.1123/ ijsn.4.3.299.

105. Froberg K, Pedersen PK. Sex differences in endurance capacity and metabolic response to prolonged, heavy exercise. Eur J Appl Physiol. 1984; 52(4):446-50. https://doi.org/10.1007/BF00943378.

106. Carter SL, Rennie C, Tarnopolsky MA. Substrate utilization during endurance exercise in men and women after endurance training. Am J Physiol. 2001; 280:898-907.

107. Spriet LL, Gibala MJ. Nutritional strategies to influence adaptations to training. J Sports Sci. 2004;22(1):127-41. https://doi.org/10.1080/0264041031 000140608.

108. Enette Larson-Meyer D, Newcomer BR, Hunter GR. Influence of endurance running and recovery diet on intramyocellular lipid content in women: a $1 \mathrm{H}$ NMR study. Am J Physiol. 2002;282:95-106.

109. Stokes T, Hector AJ, Morton RW, McGlory C, Phillips SM. Recent perspectives regarding the role of dietary protein for the promotion of muscle hypertrophy with resistance exercise training. Nutrients; 2018 [Cited 2020 Apr 13]. Available from: https://www.ncbi.nlm.nih.gov/pubmed/29414855

110. Wang X, Proud CG. The mTOR pathway in the control of protein synthesis. Physiology. 2006:362-9.

111. Wolfe RR, Miller SL. The recommended dietary allowance of protein: A misunderstood concept. JAMA. 2008:2891-3. https://doi.org/10.1001/jama.2 99.24.2891.

112. Humayun MA, Elango R, Ball RO, Pencharz PB. Reevaluation of the protein requirement in young men with the indicator amino acid oxidation technique. Am J Clin Nutr. 2007;86:995-1002 Available from: https:// pubmed.ncbi.nlm.nih.gov/17921376/ [cited 20209 Nov].

113. Morton RW, Murphy KT, McKellar SR, Schoenfeld BJ, Henselmans M, Helms $\mathrm{E}$, et al. A systematic review, meta-analysis and meta-regression of the effect of protein supplementation on resistance training-induced gains in muscle mass and strength in healthy adults. Br J Sports Med. 2018;52:376-84.

114. Tarnopolsky M. Protein requirements for endurance athletes. Nutrition. 2004: 662-8 Available from: https://pubmed.ncbi.nlm.nih.gov/15212749/[cited 202016 Nov].

115. Kriengsinyos W, Wykes $L$, Goonewardene $L A$, Ball RO, Pencharz PB. Phase of menstrual cycle affects lysine requirement in healthy women. Am J Physiol Endocrinol Metab [Internet]. 2004 ; 287: E489-E496. Available from: https:// www.ncbi.nlm.nih.gov/pubmed/15308475 [cited 202015 Apr]

116. Draper CF, Duisters K, Weger B, Chakrabarti A, Harms AC, Brennan L, et al. Menstrual cycle rhythmicity: metabolic patterns in healthy women. Sci Rep. 2018:8.

117. Lamont LS, Lemon PWR, Bruot BC. Menstrual cycle and exercise effects on protein catabolism. Med Sci Sports Exerc. 1987;19(2):106-10. 
118. Bandegan A, Courtney-Martin G, Rafii M, Pencharz PB, Lemon PW. Indicato Amino Acid-Derived Estimate of Dietary Protein Requirement for Male Bodybuilders on a Nontraining Day Is Several-Fold Greater than the Current Recommended Dietary Allowance. J Nutr. 2017;147:850-7 Available from: http://www.ncbi.nlm.nih.gov/pubmed/28179492 [cited 202024 Mar].

119. Malowany JM, West DWD, Williamson E, Volterman KA, Abou Sawan S, Mazzulla $\mathrm{M}$, et al. Protein to Maximize Whole-Body Anabolism in Resistance-trained Females after Exercise. Med Sci Sports Exerc. 2019;51:798-804 Available from: https://www.researchgate.net/publication/328692335 [cited 202024 Mar].

120. Bosse JD, Dixon BM. Dietary protein to maximize resistance training: a review and examination of protein spread and change theories. J Int Soc Sports Nutr; 2012 [cited 2020 Apr 13]. p. 42. Available from: https://jissn. biomedcentral.com/articles/10.1186/1550-2783-9-42

121. Houltham SD, Rowlands DS. A snapshot of nitrogen balance in endurancetrained women. Appl Physiol Nutr Metab. 2014;39:219-25 Available from: https://www.nrcresearchpress.com/doi/10.1139/apnm-2013-0182 [cited 2020 $13 \mathrm{Apr}]$.

122. Areta JL, Burke LM, Ross ML, Camera DM, West DWD, Broad EM, et al. Timing and distribution of protein ingestion during prolonged recovery from resistance exercise alters myofibrillar protein synthesis. J Physiol; 2013; 591: 2319-2331. Available from: https://doi.wiley.com/10.1113/jphysiol.2 012.244897 [cited $202013 \mathrm{Apr}$ ]

123. Tipton KD, Rasmussen BB, Miller SL, Wolf SE, Owens-Stovall SK, Petrini BE, et al. Timing of amino acid-carbohydrate ingestion alters anabolic response of muscle to resistance exercise. Am J Physiol. 2001:281.

124. Josse AR, Tang JE, Tarnopolsky MA, Phillips SM. Body composition and strength changes in women with milk and resistance exercise. Med Sci Sports Exerc. 2010;42(6):1122-30. https://doi.org/10.1249/MSS.0b013e3181 c854f6.

125. Pihoker AA, Peterjohn AM, Trexler ET, Hirsch KR, Blue MNM, Anderson KC, et al. The effects of nutrient timing on training adaptations in resistancetrained females. J Sci Med Sport; 2019; 22: 472-477. Available from: https:// pubmed.ncbi.nlm.nih.gov/30366741/ [cited 202016 Nov]

126. Wingfield HL, Smith-Ryan AE, Melvin MN, Roelofs EJ, Trexler ET, Hackney AC, et al. The acute effect of exercise modality and nutrition manipulations on post-exercise resting energy expenditure and respiratory exchange ratio in women: a randomized trial. Sport Med; 2015 ; 1: 11. Available from: https:// www.ncbi.n/m.nih.gov/pubmed/27747847 [cited 202016 Nov]

127. Carbone JW, McClung JP, Pasiakos SM. Recent advances in the characterization of skeletal muscle and whole-body protein responses to dietary protein and exercise during negative energy balance. Adv Nutr. 2019. p. 70-79. Available from: https://doi.org/10.1093/advances/nmy087, 2019 [cited 202014 Apr]

128. Krishnan S, Tryon R, Welch LC, Horn WF, Keim NL. Menstrual cycle hormones, food intake, and cravings. FASEB J [Internet]. John Wiley \& Sons, Ltd; [cited 2020 Dec 3];30:418.6-418.6. Available from: https://faseb. onlinelibrary.wiley.com/doi/full/10.1096/fasebj.30.1_supplement.418.6

129. Trexler ET, Smith-Ryan A, Stout JR, Hoffman JR, Wilborn CD, Sale C, et al. International society of sports nutrition position stand: Beta-Alanine. J Int Soc Sports Nutr ; 2015;12:1-14. Available from: https://doi.org/10.1186/s12 970-015-0090-y 1

130. Stegen S, Bex T, Vervaet C, Vanhee L, Achten E, Derave W. $\beta$-Alanine dose for maintaining moderately elevated muscle carnosine levels. Med Sci Sports Exerc. 2014;46:1426-32.

131. Varanoske AN, Hoffman JR, Church DD, Coker NA, Baker KM, Dodd SJ, et al. B-Alanine supplementation elevates intramuscular carnosine content and attenuates fatigue in men and women similarly but does not change muscle L-histidine content. Nutr Res. 2017;48:16-25.

132. Varanoske AN, Hoffman JR, Church DD, Wang R, Baker KM, Dodd SJ, et al. Influence of skeletal muscle carnosine content on fatigue during repeated resistance exercise in recreationally active women. Nutrients. 2017;9:1-14.

133. Varanoske AN, Hoffman JR, Church DD, Coker NA, Baker KM, Dodd SJ, et al. Comparison of sustained-release and rapid-release $\beta$-alanine formulations on changes in skeletal muscle carnosine and histidine content and isometric performance following a muscle-damaging protocol. Amino Acids; 2019; 51: 49-60. Available from: https://doi.org/10.1007/s00726-018-2609-4, 2019.

134. Smith-Ryan A, Fukuda DH, Stout JR, Kendall KL. High-velocity intermittent running: Effects of beta-alanine supplementation. J Strength Cond Res [Internet]. 2012; 26: 2798-2805. Available from: https://www.ncbi.nlm.nih. gov/pubmed/22797003 [cited 202024 Apr]
135. Harris RC, Tallon MJ, Dunnett M, Boobis L, Coakley J, Kim HJ, et al. The absorption of orally supplied $\beta$-alanine and its effect on muscle carnosine synthesis in human vastus lateralis. Amino Acids. 2006;30(3):279-89. https:// doi.org/10.1007/s00726-006-0299-9.

136. MacPhee S, Weaver IN, Weaver DF. An evaluation of Interindividual responses to the orally administered neurotransmitter $\beta$-alanine. J Amino Acids Hindawi Limited. 2013;2013:1-5. https://doi.org/10.1155/2 013/429847.

137. Keisler BD, Armsey TD. Caffeine as an ergogenic aid. Curr Sports Med Rep. 2006;5(4):215-9. https://doi.org/10.1097/01.CSMR.0000306510.57644.a7.

138. Guest NS, VanDusseldorp TA, Nelson MT, Grgic J, Schoenfeld BJ, Jenkins NDM, et al. International society of sports nutrition position stand: caffeine and exercise performance. J Int Soc Sports Nutr. 2021:1 Available from: https://creativecommons.org/licenses/by/4.0/.TheCrea tiveCommonsPublicDomainDedicationwaiver [cited 20215 Feb].

139. Lane JD, Steege JF, Rupp SL, Kuhn CM. Menstrual cycle effects on caffeine elimination in the human female. Eur J Clin Pharmacol. 1992;43(5):543-6. https://doi.org/10.1007/BF02285099.

140. Smith A. Effects of caffeine on human behavior. Food Chem Toxicol. 2002: 1243-55.

141. Nawrot $P$, Jordan S, Eastwood J, Rotstein J, Hugenholtz A, Feeley M. Effects of caffeine on human health. Food Addit Contam. 2003:1-30.

142. Graham TE. Caffeine and exercise metabolism, endurance and performance. Sport Med. 2001;31(11):785-807. https://doi.org/10.2165/00007256-20013111 0-00002.

143. Goldstein ER, Jacobs PL, Whitehurst M, Penhollow T, Antonio J. Caffeine enhances upper body strength in resistance-trained women. J Int Soc Sports Nutr. 2010;7:1-6.

144. Harris RC, Soderlund K, Hultman E. Elevation of creatine in resting and exercised muscle of normal subjects by creatine supplementation. Clin Sci. 1992;83:367-74 Available from: https://pubmed.ncbi.nlm.nih.gov/1327657/ [cited 20213 Feb].

145. Buford TW, Kreider RB, Stout JR, Greenwood M, Campbell B, Spano M, et al. International Society of Sports Nutrition position stand: Creatine supplementation and exercise. J Int Soc Sports Nutr. 2007:6 Available from: https://jissn.biomedcentral.com/articles/10.1186/1550-2783-4-6 [cited 20213 Feb].

146. Kreider RB, Kalman DS, Antonio J, Ziegenfuss TN, Wildman R, Collins R, et al. International Society of Sports Nutrition position stand: Safety and efficacy of creatine supplementation in exercise, sport, and medicine. J Int Soc Sports Nutr. 2017:1-18 Available from: https://jissn.biomedcentral.com/a rticles/10.1186/s12970-017-0173-z [cited 20215 Feb].

147. Ellery SJ, Walker DW, Dickinson H. Creatine for women: a review of the relationship between creatine and the reproductive cycle and femalespecific benefits of creatine therapy. Amino Acids. 2016;48(8):1807-17. https://doi.org/10.1007/s00726-016-2199-y.

148. Ainsley Dean PJ, Arikan G, Opitz B, Sterr A. Potential for use of creatine supplementation following mild traumatic brain injury. Concussion. 2017; 2(2):CNC34. https://doi.org/10.2217/cnc-2016-0016.

149. Kreider RB, Kalman DS, Antonio J, Ziegenfuss TN, Wildman R, Collins R, et al. International Society of Sports Nutrition position stand: Safety and efficacy of creatine supplementation in exercise, sport, and medicine. J Int Soc Sports Nutr. 2017;14:1-19.

150. Cooper R, Naclerio F, Allgrove J, Jimenez A. Creatine supplementation with specific view to exercise/sports performance: An update. J Int Soc Sports Nutr; 2012;9:1. Available from: ???

151. Tarnopolsky MA, MacLennan DP. Creatine monohydrate supplementation enhances high-intensity exercise performance in males and females. Int J Sport Nutr. 2000;10:452-63.

152. Ayoama R, Hiruma E, Sasaki H. Effects of creatine loading on muscular strength and endurance of female softball players. J Sports Med Phys Fitness. 2003:43(4):481-7.

153. Kerksick CM, Wilborn CD, Roberts MD, Smith-Ryan A, Kleiner SM, Jäger R, et al. ISSN exercise \& sports nutrition review update: Research \& recommendations. J Int Soc Sports Nutr. 2018;15:1-57.

154. Eckerson JM. Creatine as an Ergogenic Aid for Female Athletes. Strength Cond J. 2016;38:14-23 Available from: https://journals.Iww.com/00126548-2 01604000-00004 [cited 20215 Feb].

155. Simopoulos AP. Omega-3 fatty acids in inflammation and autoimmune diseases. J Am Coll Nutr. 2002;21(6):495-505. https://doi.org/10.1080/0731 5724.2002.10719248. 
156. Hibbeln JR, Gow RV. The potential for military diets to reduce depression, suicide, and impulsive aggression: a review of current evidence for Omega3 and Omega-6 fatty Acids. Mil Med. 2014;179(11S):117-28. https://doi.org/1 0.7205/MILMED-D-14-00153.

157. Swanson D, Block R, Mousa SA. Omega-3 fatty Acids EPA and DHA : health. J Adv Nutr. 2012;3:1-7. Available from: https://advances.nutrition.org/ content/3/1/1.short. https://doi.org/10.3945/an.111.000893.

158. Vincent JU. Federal Register. Fed Regist. 2010;75:56928-35.

159. West NP, Pyne DB, Peake JM, Cripps AW. Probiotics, immunity and exercise: a review. Exerc Immunol Rev. 2009;15:107-26.

160. Jäger R, Mohr AE, Carpenter KC, Kerksick CM, Purpura M, Moussa A, et al. International Society of Sports Nutrition Position Stand: probiotics. J Int Soc Sports Nutr. 2019:62 Available from: https://doi.org/10.1186/s12970-019-032 9-0, 2019 [cited 2021 Feb 5].

161. Lamprecht M, Bogner S, Schippinger G, Steinbauer K, Fankhauser F, Hallstroem $S$, et al. Probiotic supplementation affects markers of intestinal barrier, oxidation, and inflammation in trained men; a randomized, doubleblinded, placebo-controlled trial. J Int Soc Sports Nutr. 2012;9:1-13.

162. Akgül T, Karakan T. The role of probiotics in women with recurrent urinary tract infections. Turkish J Urol; 2018. p. 377-383. Available from: /pmc/ articles/PMC6134985/?report=abstract [cited 202014 Jul]

163. Axling U, Önning G, Combs MA, Bogale A, Högström M, Svensson M. The Effect of Lactobacillus plantarum 299v on Iron Status and Physical Performance in Female Iron-Deficient Athletes: A Randomized Controlled Trial. Nutrients. 2020;12:1279 Available from: https://www.mdpi.com/20726643/12/5/1279 [cited 20214 Mar].

164. West NP, Pyne DB, Cripps AW, Hopkins WG, Eskesen DC, Jairath A, et al. Lactobacillus fermentum (PCC) supplementation and gastrointestinal and respiratory-tract illness symptoms: A randomised control trial in athletes. Nutr J. 2011:10 Available from: https://pubmed.ncbi.n/m.nih.gov/21477383/ [cited $20214 \mathrm{Mar}$.

165. Stecker RA, Moon JM, Russo TJ, Ratliff KM, Mumford PW, Jäger R, et al. Bacillus coagulans GBI-30, 6086 improves amino acid absorption from milk protein. Nutr Metab. 2020;17:93 Available from: https://nutritionandmeta bolism.biomedcentral.com/articles/10.1186/s12986-020-00515-2 [cited 2021 $4 \mathrm{Mar}$.

166. Kligler B, Cohrssen A. Probiotics Am Fam. Physician. American Academy of Family Physicians; 2008. p. 1073-8.

167. Zdzieblik D, Oesser S, Baumstark MW, Gollhofer A, König D. Collagen peptide supplementation in combination with resistance training improves body composition and increases muscle strength in elderly sarcopenic men: a randomised controlled trial. Br J Nutr. 2015;114(8):1237-45. https://doi. org/10.1017/S0007114515002810.

168. Antonio J, Sanders MS, Ehler LA, Uelmen J, Raether JB, Stout JR. Effects of exercise training and amino-acid supplementation on body composition and physical performance in untrained women. Nutrition. 2000;16(11-12): 1043-6. https://doi.org/10.1016/S0899-9007(00)00434-2.

169. Kerksick CM, Arent S, Schoenfeld BJ, Stout JR, Campbell B, Wilborn CD, et al. International society of sports nutrition position stand: nutrient timing. J Int Soc Sports Nutr. 2017;14:1-21.

170. Hoffman JR, Falvo MJ. Protein - Which is best? J Sport Sci Med. 2004;3:118-30.

171. Gorissen SHM, Crombag JJR, Senden JMG, Waterval WAH, Bierau J, Verdijk $L B$, et al. Protein content and amino acid composition of commercially available plant-based protein isolates. Amino Acids [Internet]. SpringerVerlag Wien; 2018 [cited 2020 Jul 14];50:1685-95. Available from: /pmc/ articles/PMC6245118/?report=abstract.

172. Jäger R, Zaragoza J, Purpura M, lametti S, Marengo M, Tinsley GM, et al. Probiotic Administration Increases Amino Acid Absorption from Plant Protein: a Placebo-Controlled, Randomized, Double-Blind, Multicenter, Crossover Study. Probiotics Antimicrob Proteins [Internet]. Springer; 2020 [cited 2021 mar 4];12:1330-9. Available from: https://doi.org/10.1007/s12602020-09656-5.

173. Brown MA, Stevenson EJ, Howatson G. Whey protein hydrolysate supplementation accelerates recovery from exercise-induced muscle damage in females. Appl Physiol Nutr Metab. 2018;43(4):324-30. https://doi. org/10.1139/apnm-2017-0412.

174. Wan JJ, Qin Z, Wang PY, Sun Y, Liu X. Muscle fatigue: general understanding and treatment. Exp. Mol. Med. Nature Publishing Group; 2017.

175. Dietary Reference Intakes for Thiamin, Riboflavin, Niacin, Vitamin B6, Folate, Vitamin B12, Pantothenic Acid, Biotin, and Choline. Diet. Ref. Intakes
Thiamin, Riboflavin, Niacin, Vitam. B6, Folate, Vitam. B12, Pantothenic Acid, Biot. Choline. National Academies Press; 1998.

176. Riboflavin - Health Professional Fact Sheet [Internet]. [cited 2020 Jul 15]. Available from: https://ods.od.nih.gov/factsheets/Riboflavin-Hea IthProfessional/

177. Jäger R, Kerksick CM, Campbell BI, Cribb PJ, Wells SD, Skwiat TM, et al. International Society of Sports Nutrition Position Stand: Protein and exercise. J Int Soc Sports Nutr. 2017;14:1-25.

178. Ross C, Taylor C, Yaktine A, Del Valle H. Dietary reference intakes for calcium and vitamin D. Diet Ref Intakes Calcium Vitam D 2011.

\section{Publisher's Note}

Springer Nature remains neutral with regard to jurisdictional claims in published maps and institutional affiliations.
Ready to submit your research? Choose BMC and benefit from:

- fast, convenient online submission

- thorough peer review by experienced researchers in your field

- rapid publication on acceptance

- support for research data, including large and complex data types

- gold Open Access which fosters wider collaboration and increased citations

- maximum visibility for your research: over $100 \mathrm{M}$ website views per year

At BMC, research is always in progress.

Learn more biomedcentral.com/submissions 